\title{
Vaccine Passports as a Constitutional Right
}

\section{Working Paper}

Author(s):

Cope, Kevin; Somin, Ilya; Stremitzer, Alexander (D)

Publication date:

2021-08

Permanent link:

https://doi.org/10.3929/ethz-b-000504018

\section{Rights / license:}

In Copyright - Non-Commercial Use Permitted

\section{Originally published in:}

Center for Law \& Economics Working Paper Series 2021(10) 


\section{$\boldsymbol{G H}$ zürich}

\section{Center for Law \& Economics Working Paper Series}

Number 10/2021

Vaccine Passports as a Constitutional Right

Kevin L. Cope

Ilya Somin

Alexander Stremitzer 


\title{
VACCINE PASSPORTS AS A CONSTITUTIONAL RIGHT
}

\author{
Kevin Cope, ${ }^{*}$ Ilya Somin,$^{\dagger} \&$ Alexander Stremitzer ${ }^{\ddagger}$
}

Does the U.S. Constitution guarantee a right to a vaccine passport? In the United States and elsewhere, vaccine passports have existed for over a century, but have recently become politically divisive as applied to COVID19. A consensus has emerged among legal experts that vaccine passports are often constitutionally permissible. Yet there has been almost no serious analysis about whether a vaccine passport can be a constitutional right: whether a government is constitutionally obligated to exempt fully vaccinated people from many liberty-restricting measures. While some measures may be unconstitutional regardless of to whom they apply, we argue that there exist certain public-health restrictions from which the vaccinated must constitutionally be exempted, even if the vaccinated need not be. The government is never constitutionally obligated to impose liberty-restricting measures in response to an epidemic. But where it does so, it often has an obligation to exempt those who, being successfully vaccinated, pose little danger of transmitting the disease or suffering serious illness. Under U.S. constitutional law, vaccinated people might be entitled to exemptions from six sets of restrictions: (1) domestic travel and movement, under Fourteenth Amendment substantive due process; (2) international travel; (3) uncompensated shutdowns, under the Fifth Amendment takings clause; (4) abortion, under the constitutional right to privacy; (5) restrictions on access to gun stores, under the Second Amendment; and (6) assembly and worship, under the First Amendment freedom of assembly and free exercise clauses. Contrary to some arguments based in liberty and social-justice principles, this conclusion is also consistent with longstanding liberal values of fair allocation of costs, liberty, non-discrimination, and equity.

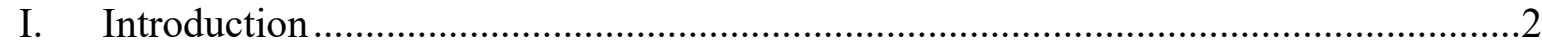

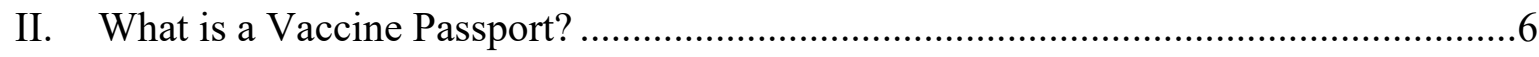

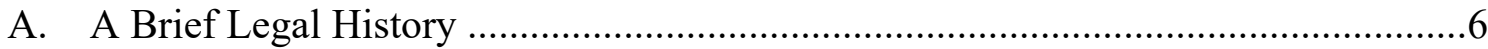

B. The COVID-19 Vaccine ................................................................................. 8

\footnotetext{
* Associate Professor of Law and Public Policy, University of Virginia. We thank Samuel Bray, Anna Forgacs, Richard Re, Robert Thomas, Shelley Saxer, Kevin Tobias, Eugene Volokh, and Luke Wake for helpful suggestions and feedback. We thank Apinop Atipiboonsin, Jeffrey Horn, and Leigha Wentz for excellent research assistance.

${ }^{\dagger}$ Professor of Law, George Mason University.

¥ Professor of Law, Economics, and Business, ETH Zurich; Scientific Co-Director, ETH Decision Science Laboratory; Visiting Professor of Law, Senior Scholar in Residence, UCLA School of Law.
} 


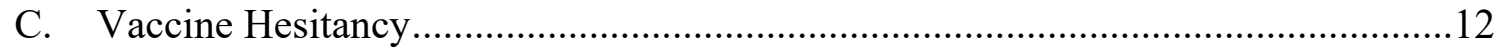

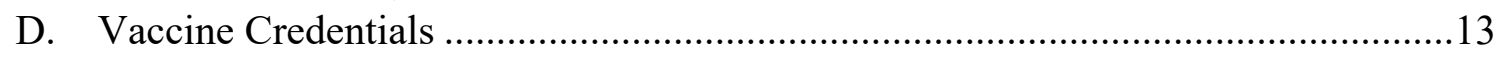

E. Restriction Exemption Programs ………………...................................................14

1. Independently Imposed by Private Organizations .................................................15

2. Directly Government-Imposed ………………….......................................16

3. Government-Imposed Through Private Organizations ........................................17

III. The Constitutional Permissibility of Vaccine Passports ..............................................17

A. The Constitutionality of Vaccine Mandates..........................................................18

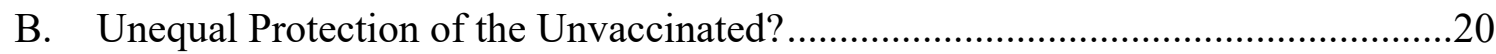

IV. Vaccine Passports as a Constitutional Right...............................................................24

A. Domestic Movement and Travel Under Fourteenth Amendment Substantive Due

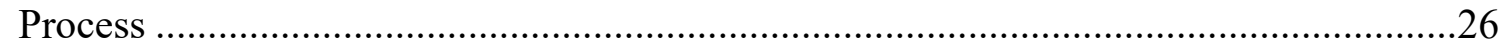

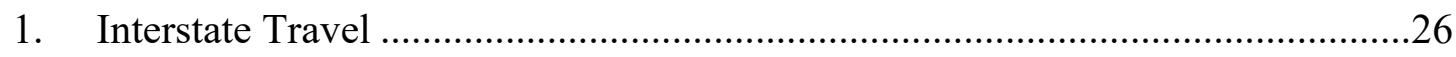

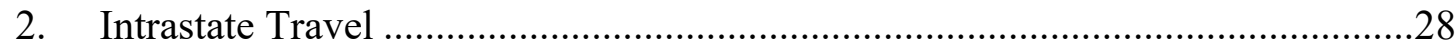

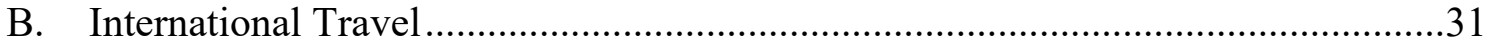

C. Challenges to Shutdowns Under the Fifth Amendment Takings Clause ..................32

D. Abortion Under the Constitutional Right to Privacy .................................................38

E. Lockdown Restrictions on the Second Amendment Right to Bear Arms.................39

F. Restrictions on Assembly and Religious Gatherings Under the First Amendment 40

V. The Ethics of Discrimination on the Basis of Vaccination Status ...............................42

A. Fair Allocation of Costs and Incentivizing Vaccination ............................................43

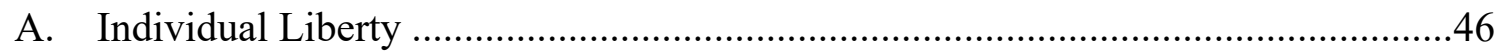

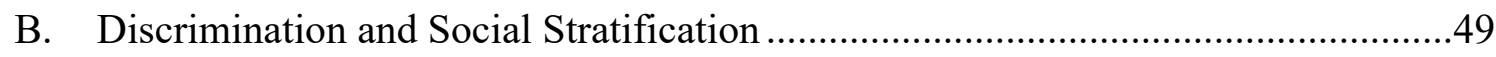

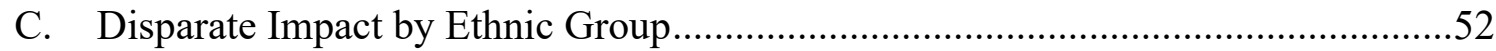

VI. Practical Challenges to Judicially Mandated Vaccine Passports ..................................54

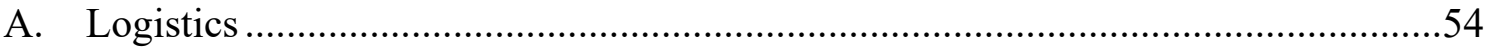

B. Relevance Through an Evolving Pandemic ………...........................................56

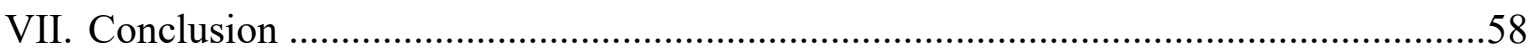

\section{INTRODUCTION}

Vaccine passports have been a source of controversy for over a century. In 1897, after initial resistance and extensive negotiations between the U.K. government and other stakeholders, authorities required the millions of annual pilgrims to the British colonial 
Indian town of Pandharpur, Bombay, to prove they had been vaccinated against the plague. ${ }^{1}$ At the turn of the twentieth century, a smallpox vaccine had existed in some form for over 100 years, but its safety record was dubious. Nonetheless, as the smallpox scourge continued, physicians began calling on business owners and government officials to require proof of smallpox vaccination (which then meant showing the distinctive upper-arm vaccination scar) as a "passport" for participation in various work and social activities. Many heeded this call, and border officials and employers began demanding the smallpox passport as a condition of entry or participation. ${ }^{2}$ Since the mid-twentieth-century, travel to certain parts of Africa and South America has been restricted to those who have been vaccinated against yellow fever, validated via a World Health Organization document called the "yellow card." each of these cases, vaccine passports met legal and political resistance from those who opposed making access to public spaces conditional on vaccination.

The 2020 COVID-19 pandemic brought these debates back to the fore. Since its onset, COVID-19 has spurred a new global discourse about how society balances liberty and safety in public-health policy. ${ }^{4}$ The introduction of effective vaccines one year into the pandemic added a new wrinkle to this discussion. Policymakers, public-health experts, and the general public have wrestled with one question in particular: until the virus is eradicated, who should be freed from the restrictions? No one? Everyone? Or only the vaccinated?

In the United States and elsewhere, the idea of a vaccine passport is politically divisive: a slim majority of Americans said in April 2021 that they support them, ${ }^{5}$ though views on the issue do not always divide Americans neatly along the typical left-right lines. ${ }^{6}$ Some U.S. conservatives said they opposed the government's coercing people into a medical procedure while withholding rights and privileges from those opting out. ${ }^{7}$ Relatedly, unequal vaccination levels between demographic groups have made some progressives wary of the proposal to restore rights to the vaccinated, especially in countries where the vaccine was

\footnotetext{
${ }^{1}$ Fran Kritz, The Vaccine Passport Debate Actually Began In 1897 Over A Plague Vaccine, NPR: GoATs AND SoDA (Apr. 8, 2021, 4:18 PM), https://www.npr.org/sections/goatsandsoda/2021/04/08/985032748/thevaccine-passport-debate-actually-began-in-1897-over-a-plague-vaccine/.

${ }^{2}$ See Jordan E. Taylor, The U.S. Has Had 'Vaccine Passports' Before-And They Worked, Time (Apr. 5, 2021), https://time.com/5952532/vaccine-passport-history/ (noting that "[t] oward the end of the Civil War" began to treat smallpox scars as a "vaccine passport).

3 Mark D. Gershman \& J. Erin Staples, Yellow Fever, CDC (June 11, 2021), https://wwwnc.cdc.gov/travel/yellowbook/2020/travel-related-infectious-diseases/yellow-fever\#2849.

${ }^{4}$ See generally Adam Chilton, Kevin L. Cope, Charles Crabtree, \& Mila Versteeg. The Normative Force of Higher-Order Law: Evidence from Six Countries During the COVID-19 Pandemic (unpublished manuscript), available at https://privpapers.ssrn.com/sol3/papers.cfm?abstract id=3591270.

${ }^{5}$ Gabriela Schulte, Poll: 53 Percent of Voters Support Having 'Vaccine Passports, HiLl (Apr. 6, 2021), https://thehill.com/hilltv/what-americas-thinking/546978-poll-53-percent-of-voters-support-govt-createdvaccine.

6 See, e.g., Vinay Prasad, Vax Passports Are a Bad Idea, MedPage Today (Apr. 15, 2021), https://www.medpagetoday.com/opinion/vinay-prasad/92107.

${ }^{7}$ See, e.g., Noah Wall, Following DeSantis, Conservatives Everywhere Must Reject Vaccine Passports, WASH. TIMES (June 26, 2021), https://www.washingtontimes.com/news/2021/jun/26/following-desantisconservatives-everywhere-must-r/.
} 
not yet widely available. ${ }^{8}$ Partly for these reasons, legal experts and others in the United States have debated whether a government-run vaccine passport program would even be constitutional. ${ }^{9}$ Nonetheless, vaccine passport programs were implemented in several countries and jurisdictions around the world, including Israel, Switzerland, the European Union, San Francisco, and New York State. ${ }^{10}$

In the debate about vaccine passports' constitutionality, there has been surprisingly little discussion of whether a government might be constitutionally obligated to exempt fully vaccinated people from many liberty-restricting measures-in other words, whether exemptions for the immunized were not just legally permissible, but a constitutional right. We argue that, indeed, the government is constitutionally required to exempt the vaccinated from certain restrictions of liberty. Though many U.S. jurisdictions are quite unlikely to create a comprehensive vaccine passport system via legislation or executive regulations, vaccine passports could nonetheless still emerge judicially. Where a government imposes liberty-restricting measures in response to an infectious disease epidemic, it carries an obligation to exempt those who, being fully immunized with an effective vaccine, pose relatively little danger of transmitting the disease or of suffering serious illness. Specifically, vaccinated people may be entitled to exemptions from several sets of restrictions: (1) domestic travel and movement, under Fourteenth Amendment substantive due process; (2) international travel; (3) uncompensated shutdowns under the Fifth Amendment takings clause; (4) abortion, under the constitutional right to privacy; (5) restrictions on access to gun stores, under the Second Amendment; and (6) assembly and worship, under the First Amendment freedom of assembly and free exercise clauses.

To secure exemption, an immunized person who is subjected to certain public-healthrelated restrictions might file suit against the (likely state or local) government that is imposing these restrictions, citing one or more of these provisions. For relief, she would seek an order enjoining the government-defendant from applying the pertinent restriction(s) to her. In most cases, it would likely be easier for the government to simply exempt the entire set of immunized, potential future plaintiffs than to create special rules for an individual or small set of people.

\footnotetext{
${ }^{8}$ Seema Mohapatra, Passports of Privilege, _ AM. U.L. REv. 101 (forthcoming 2021) (arguing that vaccine passport programs are legal but unethical, primarily because they exacerbate inequity)

9 E.g., Lawrence Gostin, Are Covid-19 Vaccine Passports Legal?, ForBeS (Apr. 13, 2021), https://www.forbes.com/sites/coronavirusfrontlines/2021/04/13/are-covid-19-vaccine-passports-legal/; Legal Questions Surround 'Vaccine Passports', NPR (Apr. 10, 2021), https://www.npr.org/2021/04/10/986125489/legal-questions-surround-vaccine-passports; Glen Martin, Vaccine Passports: Are They Legal-Or Even a Good Idea?, (Apr. 19, 2021), https://alumni.berkeley.edu/california-magazine/just-in/2021-04-19/vaccine-passports-are-they-legal-oreven-good-idea; Sheryl Gay Stolberg \& Adam Liptak, Likely Legal, 'Vaccine Passports' Emerge as the Next Coronavirus Divide, N.Y. TIMES (Apr. 6, 2021), https://www.nytimes.com/2021/04/06/us/politics/vaccinepassports-coronavirus.html. For analysis of their legality in Canada, see Bryan Thomas, Colleen M. Flood, Vivek Krishnamurthy, Ryan Tanner, \& Kumanan Wilson, Vaccine Ins and Outs: An Exploration of the Legal Issues Raised by Vaccine Passports (C.D. Howe Inst., Working Paper, July 2021), https://www.cdhowe.org/sites/default/files/attachments/research_papers/mixed/Working\%20Paper\%20202107-13.pdf.

${ }^{10}$ See text accompanying notes $79-81$.
} 
Such exemptions would be not just a constitutional right, but consistent with ethical principles rooted in both social-justice and libertarian values. Mandatory vaccine passports accord with values like efficient allocation of costs, liberty, non-discrimination, and disparate impact on demographic groups. Although historical and present inequity in vaccine distribution is concerning and needs to be better addressed, the expected net effect of vaccine passports is to increase, not decrease, welfare for most everyone, including marginalized or disadvantaged people.

One reason the position we develop has been largely overlooked in popular and legal discourse is the non-traditional political alignments on this issue. Countries, states, and municipalities with conservative populations and leaders have been least likely to implement restrictive measures, in part due to skepticism among those residents about how much threat the virus posed. ${ }^{11}$ Perhaps for similar reasons, conservatives have also proven least willing to receive the COVID-19 vaccine. ${ }^{12}$ By the time vaccines were widely available, many of these conservative jurisdictions had already repealed most of their restrictions. ${ }^{13}$ The low levels of vaccination, together with low levels of restrictions, rendered moot any potential legal claim by the vaccinated for a restriction exemption. On the other hand, in jurisdictions with left-leaning leadership, residents were more likely to support or tolerate more severe restrictions. ${ }^{14}$ Those jurisdictions, like New York State, were also more willing both to adopt a standardized vaccine credential, and to permit or require discrimination on the basis of vaccination status, leaving less demand for a constitutional legal challenge.

Note that our analysis makes a series of assumptions. First, we assume that the available vaccines are reasonably safe and strongly effective at reducing the seriousness and effects of illness or effective at preventing disease transmission (either because they reduce an infected person's viral load and therefore, his contagiousness; or because they reduce the risk of even asymptomatic infection). Second, we assume that, while the vaccines need not be available to all adults, to the extent they are not universally available because of limited supply, they are offered primarily based on rational criteria, such as older age, medical conditions, or high-exposure occupations, not invalid or irrational criteria, such as socioeconomic status. Third, we assume that the relevant population has not achieved "herd immunity," that is, the state where a sufficient fraction of the population is protected via vaccination or previous infection, such that infection cannot readily spread even among the

${ }^{11}$ See Amelia Thomson-DeVeaux, Republicans and Democrats See COVID-19 Very Differently. Is That Making People Sick?, FiveTHIRTYEIGHT (July 23, 2020), https://fivethirtyeight.com/features/republicans-anddemocrats-see-covid-19-very-differently-is-that-making-people-sick/.

${ }^{12}$ Susan Milligan, Coronavirus Vaccines Highlight a Deadly Political Divide, U.S. News \& WoRLd ReP. (July 23, 2021), //www.usnews.com/news/the-report/articles/2021-07-23/coronavirus-vaccines-highlight-a-deadlypolitical-divide (presenting survey results and vaccination monitoring reports which show the reluctance of Republicans to get vaccinated).

${ }^{13}$ Tim Fitzsimons, These States Are Rolling Back Covid Restrictions, Including Mask Mandates and Indoor Capacity Caps, NBC News (Apr. 20, 2021), https://www.nbcnews.com/news/us-news/these-states-arerolling-back-covid-restrictions-including-mask-mandates-n1259751.

${ }^{14}$ See Katherine Schaeffer, Despite Wide Partisan Gaps in Views of Many Aspects of the Pandemic, Some Common Ground Exists, PEW RSCH. CTR. (Mar. 24, 2021), https://www.pewresearch.org/fact$\operatorname{tank} / 2021 / 03 / 24 /$ despite-wide-partisan-gaps-in-views-of-many-aspects-of-the-pandemic-some-commonground-exists/. 
unprotected. ${ }^{15}$ As we explain, each of these assumptions largely holds with regard to several past and present infectious-disease epidemics, including the COVID-19 pandemic.

Our argument is not limited to any particular epidemic or set of vaccines. Given that COVID-19 vaccine rollouts are projected to take years in many parts of the world, ${ }^{16}$ that new variants of COVID-19 continue to emerge, and that COVID-19 is unlikely to be the last pandemic of our lifetimes, ${ }^{17}$ the question of selective rights and benefits for the immunized will be pertinent for years to come.

Our analysis is limited in scope in two ways. First, we do not claim that the restrictions on liberty for which we advocate constitutional exemptions for the vaccinated are necessarily justified (or constitutional) even for the unvaccinated. Some public health restrictions may be unjust, unconstitutional, or both, regardless of vaccination status. But there is a wide range of restrictions that, even if constitutional for the unvaccinated, are not so for the vaccinated. Second, we cannot provide a defense of the general validity of the constitutional rights we assess. Thus, some might reject our case for a vaccine passport to protect a given constitutional right, because they do not believe the right in question exists in the first place, or, alternatively, that it might be protected by only the most minimal "rational basis" scrutiny. ${ }^{18}$ For example, this might be true of conservatives who believe there is no constitutional right to abortion, or progressives who believe property rights should get little or no judicial protection. Nonetheless, we can still make the narrower point that vaccine passports are constitutionally required in many cases where public health measures restrict constitutional rights that do deserve meaningful protection by judicial review.

The rest of this Article proceeds as follows. Part II provides a history of vaccine passports, up to and including recent efforts to condition rights and privileges on COVID19 vaccination. It describes the role that vaccine hesitancy has played in the legal and political battles in the past and more recently over a COVID-19 vaccine passport. It then examines the notion of a vaccine passport as a legal concept, explaining how the term

\footnotetext{
${ }^{15}$ Mark A. Hall \& David M. Studdert, "Vaccine Passport" Certification - Policy and Ethical Considerations, NEw ENG. J. MeD. (Mar. 31, 2021), https://www.nejm.org/doi/full/10.1056/NEJMp2104289.

16 Carrie MacMillan, Herd Immunity: Will We Ever Get There?, YALE MED. (May 21, 2021), https://www.yalemedicine.org/news/herd-immunity.

${ }_{17}$ Ananya Mandal, Could the Next Pandemic be 100 Times Worse Than COVID-19?, News Med. (June 2, 2020), https://www.news-medical.net/news/20200602/Could-the-next-pandemic-be-100-times-worse-thanCOVID-19.aspx ("As the world tries to cope with [COVID-19], Dr. Michael Herschel Greger has claimed that worse could be yet to come."); David Murdoch, The Next Once-A-Century Pandemic is Coming Sooner Than You Think - But COVID-19 Can Help Us Get Ready, Conversation (June 14, 2020), https://theconversation.com/the-next-once-a-century-pandemic-is-coming-sooner-than-you-think-but-covid19-can-help-us-get-ready-139976 (arguing that, "[i]n the next few decades, we will likely see other pandemics," which we know "because of the recent increased frequency of major epidemics (such as SARS and Ebola), and "because of social and environmental changes driven by humans that may have contributed to COVID-19's emergence"); Steven Novella, "The Next Pandemic," SCIENCE-BASED MED. (Mar. 3, 2021), https://sciencebasedmedicine.org/the-next-pandemic/ ("There are potentially thousands of viruses in the world that have the potential to become the next pandemic, and SARS-CoV-2 is far from the worst of them.").

${ }^{18}$ See, e.g., Williamson v. Lee Optical,348 U.S. 483 (1955) (establishing this low level of scrutiny for most economic regulations).
} 
denotes two distinct concepts with different legal implications: a credential of vaccination, and a government or private-run program that exempts vaccinated or otherwise immunized people from certain government restrictions or provides them other rights and privileges. Part III reviews the debates over the legality of vaccine passports; it shows why, contrary to some claims that they constitute unconstitutional discrimination, they are consistent both with liberal notions of liberty, efficiency, fairness, and equality, and with both longstanding and recent U.S. constitutional precedent. Part IV then presents the central argument of this Article: that the U.S. Constitution requires many forms of liberty restrictions - including many that governments imposed during the COVID-19 pandemic - to be tailored to restrict liberty only in ways that relate to the relevant policy objective. Restricting people who are fully vaccinated - and thus present significantly less risk to the public - from engaging in core activities is not narrowly tailored to advance the interest of public safety, nor, in some cases is it even rationally related to that objective. In addition, we argue that preventing the vaccinated from operating a business could constitute a constitutional taking, for which fair compensation would be required. Part V considers how discriminating against the nonimmunized accords with liberal principles like liberty, non-discrimination, equitable impact, and addresses arguments against vaccine passports based in social-justice and libertarian values. Part VI explains the legal logistics of a judicially created vaccine passport and explains how the Article's argument applies in light of evolving pandemic conditions and scientific research. Part VII concludes.

\section{WHAT IS A VACCINE PASSPORT?}

\section{A. A Brief Legal History}

The first policies that could have been called "vaccine passports" arose during the smallpox outbreak in the eighteenth and nineteenth centuries. ${ }^{19}$ Early in the Revolutionary War, infectious diseases caused ninety percent of fatalities in the Continental Army. ${ }^{20}$ Smallpox - which killed almost one-third of those it infected - was responsible for most of these deaths. ${ }^{21}$ Facing dwindling troop numbers, General George Washington made the smallpox inoculation compulsory for all nonimmune soldiers in $1777 .{ }^{22}$ At the time, the requirement generated significant political and religious backlash. ${ }^{23}$ But Washington's military vaccine mandate laid the groundwork both for multiple, potentially decisive U.S. battle victories and for three centuries of vaccination requirements for military

\footnotetext{
19 See Cynthia M.A. Geppert \& Reid A. Paul, The Shot That Won the Revolutionary War and is Still Reverberating, 36(7) FED. PRAC. 298, 298-99 (2019); Taylor, supra note 2 (noting that "[t]oward the end of the Civil War" began to treat smallpox scars as a "vaccine passport); Erwin Chemerinsky \& Michele Goodwin, Compulsory Vaccination Laws Are Constitutional, 110 NW. U. L. REv. 589, 596 (2016) ("In 1827, Boston was the first city to require vaccination records for children upon entering public school.").

${ }^{20}$ Geppert \& Paul, supra note 19, at 298.

${ }^{21} \mathrm{Id}$.

${ }^{22} I d$. The smallpox inoculation at that time was not vaccination but variolation, that is, exposing the subject to a small amount of the virus itself. Edward Jenner developed the world's first vaccine decades later. See id.

${ }^{23} \mathrm{Id}$.
} 
servicemembers. ${ }^{24}$ Today, entry to the military of many countries, including the United States, is conditioned upon receiving a host of vaccinations against various infectious diseases. ${ }^{25}$

To further curb the smallpox epidemic, American public health officials began to aggressively push for mass vaccination in the late $1800 \mathrm{~s}^{26}$ The smallpox vaccine was administered by "scratching pustular material" on the arm, leaving behind a "distinctive scar." ${ }^{27}$ Around the turn of the twentieth century, border officials, employers, social clubs, and schools began to treat the smallpox vaccine scar as "a sort of early vaccine passport" required for entry, and many U.S. states began authorizing the conditioning of entry into public spaces on vaccination status. Maine, for example, barred individuals from entering lumber camps "who can not show a good vaccination scar." 28 And by 1904, eleven states required proof of vaccination to attend public schools. ${ }^{29}$ When a 1922 San Antonio city ordinance barred an unvaccinated student from entering a public school, the Supreme Court upheld the law, noting the "broad discretion required for the protection of the public health." 30

Internationally, smallpox vaccine certification checks became commonplace in the middle of the twentieth century. ${ }^{31}$ Because the advent of air travel risked accelerating global smallpox spread, countries recognized the need to cooperate by enforcing smallpox vaccination checks prior to travel. ${ }^{32}$ Travelers without "government-issued smallpox vaccination certificates" were not allowed to board ships or planes. ${ }^{33}$ Still to this day, many countries require travelers to present a "yellow card," a paper credential used by the World Health Organization showing proof of vaccination for yellow fever. ${ }^{34}$

By 1980, all fifty states maintained a vaccination requirement as a condition for public school enrollment. ${ }^{35}$ And by 2003, every state required at least diphtheria and tetanus toxoids, polio, measles, and rubella vaccines. ${ }^{36}$ Most states also required the mumps,

\footnotetext{
${ }^{24} I d$.

${ }^{25} \mathrm{Id}$.

${ }^{26}$ Taylor, supra note 2 (noting that health professionals encouraged an "aggressive approach to vaccination" as the smallpox pandemic intensified "[b]y the late 19th century").

${ }^{27} I d$.

${ }^{28} \mathrm{Id}$.

${ }^{29}$ Chemerinsky \& Goodwin, supra note 19, at 596 (noting that "eleven out of then forty-five U.S. states" required vaccination "upon entering public school").

${ }^{30}$ Zucht v. King, 260 U.S. 174 (1922).

${ }^{31}$ Fran Kritz, The Vaccine Passport Debate Actually Began in 1897 Over a Plague Vaccine, NPR (Apr. 8, 2021), https://www.npr.org/sections/goatsandsoda/2021/04/08/985032748/the-vaccine-passport-debateactually-began-in-1897-over-a-plague-vaccine ("Vaccine certification checks came under the International Sanitary Regulations adopted in 1951 by WHO member states").

${ }^{32} I d$. (noting that "in the second half of the 20th century," countries enforced "smallpox vaccination certification checks ... before travel").

${ }^{33} I d$. (observing that persons failing vaccination checks "were not allowed to board ships" and were "forcibl[y] isolate[ed] at airports").

${ }^{34} I d$.

${ }^{35}$ Chemerinsky \& Goodwin, supra note 19 , at 596.

${ }^{36} \mathrm{Id}$.
} 
pertussis, and hepatitis B vaccines. ${ }^{37}$ Today, all states provide medical exemptions to school vaccination requirements, many states also provide religious exemptions, and a small number offer philosophical exemptions as well. ${ }^{38}$ Several states even require certain vaccinations for employees working in health care. ${ }^{39}$ Hospitals, for example, began adopting vaccine mandates in $2005 . .^{40}$ In 2019 , in response to a measles outbreak, New York City opted to mandate vaccination for everyone, with non-compliance incurring a $\$ 1,000$ fine. ${ }^{41}$

Apart from school admission, most non-veteran U.S. citizens alive in 2020 had probably not faced a requirement that they be vaccinated as a condition of participation in work, social activities, or travel. That changed toward the end of 2020, when the debate over how best to distribute the forthcoming COVID-19 vaccine reintroduced the public to the term "vaccine passport."

\section{B. The COVID-19 Vaccine}

In early 2020, as the world was beginning to realize the potential scope of the COVID19 pandemic, many public-health experts speculated that it would continue at least until an effective vaccine was developed and distributed; mitigation measures like distancing, testing, and increased hygiene would slow the virus, ${ }^{42}$ but they would be insufficient to eradicate it. ${ }^{43}$ In the United States and around the world, schools and places of business were ordered to close; people were ordered to stay at home except for essential travel; public gatherings (including for religious, recreational, social, and political purposes) were prohibited; face coverings were required in public and the workplace; national borders were closed to some or all; and testing was required for some groups. ${ }^{44}$ The expert consensus is that some of these measures - such as mandatory masking, physical distancing, and testing - surely mitigated the virus's impact and likely saved tens- or hundreds-of-thousands of U.S.

\footnotetext{
${ }^{37} I d$.

${ }^{38} \mathrm{Id}$.

${ }^{39}$ Teri Dobbins Baxter, Employer-Mandated Vaccination Policies: Different Employers, New Vaccines, and Hidden Risks, 2017 UTAH L. REV. 885, 900 (explaining that "seventeen states require healthcare workers to receive influenza vaccinations" and four states "require varicella (chickenpox) vaccinations for all hospital healthcare workers").

${ }^{40} I d$. at 908.

${ }^{41}$ See generally Julie D. Cantor, Mandatory Measles Vaccination in New York City - Reflections on a Bold Experiment, 381 New EnG. J. MED. 101 (2019).

${ }^{42}$ Face-covering was not part of the early COVID mitigation protocols; in fact, in early 2020, several publichealth organizations were still advising the public against wearing masks. See Maria Cramer \& Knvul Sheikh, Surgeon General Urges the Public to Stop Buying Face Masks, N.Y. Times (Feb. 2, 2020), https://www.nytimes.com/2020/02/29/health/coronavirus-n95-face-masks.html (quoting tweet from U.S. Surgeon General Jerome M. Adams: "[Masks] are NOT effective in preventing [the] general public from catching \#Coronavirus.").

${ }^{43}$ Berkeley Lovelace Jr., Dr. Anthony Fauci Warns the Coronavirus Won't Ever Be Eradicated, CNBC (July 22, 2020), https://www.cnbc.com/2020/07/22/dr-anthony-fauci-warns-the-coronavirus-wont-ever-be-totallyeradicated.html.

${ }^{44}$ Hannah Ritchie et al., Coronavirus Pandemic (COVID-19), https://ourworldindata.org/coronavirus.
} 
lives - and perhaps millions globally. The efficacy of some other severe lockdown measures is less clear. ${ }^{45}$

But despite a yearlong global lockdown, by December 2020 the number of global new infections and deaths had reached a then-all-time high, with almost 12,000 people globally - around 2,500 of them in the United States - dying of COVID each day. For context, in the United States, the death toll was similar to a 9/11-magnitude event occurring daily. The pandemic was also wreaking an economic toll. Harvard economists David Cutler and Lawrence Summers estimated that, by late 2020, its total economic cost to the United States - stemming from loss of life and health, lost work and production, and medical costs - was close to $\$ 16$ trillion, or $90 \%$ of the annual U.S. gross domestic product. ${ }^{46}$

By late 2020, several vaccines had shown promise in Phase $\mathrm{III}^{47}$ clinical trials. ${ }^{48}$ In December 2020, public-health authorities in the United Kingdom, ${ }^{49}$ United States, ${ }^{50}$ and Switzerland ${ }^{51}$ granted emergency authorization or full approval to the Pfizer-BioNTech mRNA vaccine, ${ }^{52}$ a joint venture of the American pharmaceutical/biotechnology firm, Pfizer

${ }^{45}$ It is unclear to what extent government-imposed lockdowns (as opposed to voluntary precautions) generally affected the number of people infected, in part because there was widespread non-compliance with the restrictions, and in places with the laxest measures, many people took voluntary precautions anyway. See Douglas W. Allen, Covid Lockdown Cost/Benefits: A Critical Assessment of the Literature (Apr. 2021) (unpublished manuscript), http://www.sfu.ca/ allen/LockdownReport.pdf; see also Virat Agrawal, et al., The Impact of the Covid-19 Pandemic and Policy Responses on Excess Mortality, (Nat'l Bureau Econ. Res., Working Paper No. 28930, June 2021), https://www.nber.org/system/files/working_papers/w28930/w28930.pdf (finding that severe lockdown policies did not lead to reductions in excess deaths, and may even have caused more excess deaths than they prevented); Philippe Lemoine, "The Case Against Lockdowns," CSPI (Mar. 4, 2021), https://cspicenter.org/blog/waronscience/the-case-against-lockdowns/ (finding that lockdowns failed in their purposes and may well have caused more harm than good).

${ }^{46}$ David M. Cutler \& Lawrence H. Summers, The COVID-19 Pandemic and the \$16 Trillion Virus, JAMA NETwORK (Oct. 12, 2020), https://jamanetwork.com/journals/jama/fullarticle/2771764.

${ }^{47}$ Phase III trials often involve thousands of subjects and attempt to measure the drug's efficacy and any adverse reactions. They proceed only if a drug successfully clears the first two phases, which are conducted on smaller pools of subjects. The Drug Development Process, U.S. FDA (Jan. 4, 2018), https://www.fda.gov/patients/learn-about-drug-and-device-approvals/drug-development-process.

48 COVID-19 Vaccine Tracker, London Sch. Hygiene \& Tropical Med. (Mar. 1, 2021), https://vaclshtm.shinyapps.io/ncov vaccine landscape/.

${ }^{49}$ Conditions of Authorisation for Pfizer/BioNTech COVID-19 vaccine, Med. \& HealthCARE Prod. Reg. AGENCY, Dec. 3, 2020, https://www.gov.uk/government/publications/regulatory-approval-of-pfizer-biontechvaccine-for-covid-19/conditions-of-authorisation-for-pfizerbiontech-covid-19-vaccine\#vaccine-bnt162b2-conditions-of-authorisation-under-regulation-174--2-december-2020-amended-on-30-december-2020-28january-2021-30-march-2021-19-may-2021-04-june-2021-29-july-2021.

${ }^{50}$ Katie Thomas et al., F.D.A. Clears Pfizer Vaccine, and Millions of Doses Will Be Shipped Right Away, N.Y. TIMES (Dec. 12, 2020), https://www.nytimes.com/live/2020/12/11/world/covid-19-coronavirus.

${ }^{51}$ Swissmedic grants authorisation for the first COVID-19 vaccine in Switzerland, SWISSMEDIC (Dec. 19, 2020), https://www.bag.admin.ch/bag/en/home/das-bag/aktuell/medienmitteilungen.msg-id-81761.html.

${ }^{52}$ mRNA (messenger ribonucleic acid) vaccines use mRNA to teach the body's cells how to make the $\mathrm{S}$ proteins found on the SARS-CoV-2 virus surfaces, which trigger an antibody response in advance of exposure. Mayo Clinic Staff, Different Types of COVID-19 Vaccines: How They Work, MAYO ClinIC (July 31, 2021), 
Inc., and German biotechnology firm, BioNTech SE. (In a less transparent process months before, Russian authorities had approved and distributed narrowly the Sputnik V vector vaccine, ${ }^{53}$ developed by the Gamaleya Research Institute of Epidemiology and Microbiology. $)^{54}$ Other authorizations and vaccines followed throughout 2021. Two of the most widely distributed vaccines, those developed by Pfizer-BioNTech and by the American pharmaceutical/biotechnology firm, Moderna, Inc., showed efficacy against symptomatic illness of over $90 \%$ in several clinical trials, with one trial showing Pfizer-BioNTech to be approximately 97\% effective (against pre-Delta variants). ${ }^{55}$ In other words, a vaccinated person was less than 1/10th as likely (1/30th as likely for $97 \%$ effectiveness) to develop symptomatic illness as a similarly situated non-vaccinated person. Several of the vaccines showed efficacy in preventing death at levels close to $100 \%{ }^{56}$ In addition to preventing serious illness, the vaccines proved to significantly reduce the virus's transmissibility in the infected, meaning they work well both to mitigate the disease's impact on individuals and to slow its community spread. ${ }^{57}$

https://www.mayoclinic.org/diseases-conditions/coronavirus/in-depth/different-types-of-covid-19vaccines/art-20506465.

${ }^{53}$ Vector vaccines carry part of the genetic code of the SARS-CoV-2 virus within another virus (the vector), which gives the body's cells instructions on how to make the S proteins found on the SARS-CoV-2 virus surfaces, which in turn trigger an antibody response in advance of exposure. Id.

54 Jonathan Corum \& Carl Zimmer, How Gamaleya's Vaccine Works, N.Y. Times (May 7, 2021), https://www.nytimes.com/interactive/2021/health/gamaleya-covid-19-vaccine.html.

55 See, e.g., Mark G. Thompson et al., Interim Estimates Vaccine Effectiveness of BNT162b2 and mRNA-1273 COVID-19 Vaccines in Preventing SARS-CoV-2 Infection Among Health Care Personnel, First Responders, and Other Essential and Frontline Workers - Eight U.S. Locations, CDC (Apr. 2, 2021), https://www.cdc.gov/mmwr/volumes/70/wr/mm7013e3.htm?s cid=mm7013e3 w (finding that the Moderna and Pfizer-BioNTech vaccines are 90\% effective at preventing COVID-19 infection in real-world settings); Real-world Evidence Confirms High Effectiveness of Pfizer-biontech Covid-19 Vaccine and Profound Public Health Impact of Vaccination One Year After Pandemic Declared, PFIZER (Mar. 11, 2021), https://www.pfizer.com/news/press-release/press-release-detail/real-world-evidence-confirms-high-

effectiveness-pfizer (finding the Pfizer-BioNTech vaccine "was at least 97\%" effective "in preventing symptomatic disease"); Pfizer and Biontech Confirm High Efficacy and No Serious Safety Concerns Through up to Six Months Following Second Dose in Updated Topline Analysis of Landmark Covid-19 Vaccine Study, PFIZER (Apr. 1, 2021), https://www.pfizer.com/news/press-release/press-release-detail/pfizer-and-biontechconfirm-high-efficacy-and-no-serious (finding the Pfizer-BioNTech vaccine is $91.3 \%$ effective at preventing COVID-19 infection); Moderna Provides Clinical and Supply Updates on COVID-19 Vaccine Program Ahead of 2nd Annual Vaccines Day, Moderna (Apr. 13, 2021), https://investors.modernatx.com/newsreleases/news-release-details/moderna-provides-clinical-and-supply-updates-covid-19-vaccine (finding the Moderna vaccine's effectiveness at preventing COVID-19 infection to be "greater than 90\%").

${ }^{56}$ See, e.g., Hiam Chemaitelly et al., mRNA-1273 COVID-19 Vaccine Effectiveness Against the B.1.1.7 And B.1.351 Variants and Severe COVID-19 Disease in Qatar, 2021 NATURE MED. 1 (finding the Moderna vaccine was up to $99.9 \%$ effective at preventing "severe, critical, or fatal COVID-19 disease"); Laith J Abu-Raddad, Hiam Chemaitelly, \& Adeel A Butt, Effectiveness of the BNT162b2 Covid-19 Vaccine Against the B.1.1.7 and B.1.351 Variants, 385 New ENG. J. Med. 187, 187-189 (2021) (finding the Pfizer-BioNTech vaccine 97.4\% effective at preventing "severe, critical, or fatal disease").

${ }^{57}$ Matan Levine-Tiefenbrun et al., Initial Report of Decreased Sars-cov-2 Viral Load After Inoculation with the Bnt162b2 Vaccine, 27(5) NATURE MED. 790-92 (2021) (finding the COVID-19 vaccines "reduce viral load in breakthrough infection" and therefore "suppress onward transmission"). 
For the fully vaccinated, the risks of COVID-19 for those who did contract it were roughly analogous to those presented by the common seasonal flu, which commonly has a U.S. mortality rate of about 1 in $6,500 .{ }^{58}$ Evidence from summer 2021 suggests that vaccination provided somewhat less protection against the more contagious "Delta" variant, ${ }^{59}$ and that those vaccinated who did contract it could transmit it to the unvaccinated, but that a third shot of the Pfizer-BioNTech vaccine could boost immunity against this strain. ${ }^{60}$ Later studies conducted after this more-infectious variant developed suggested that the fully vaccinated were three-to-eight times less likely to contract even an asymptomatic infection and were therefore far less likely to contribute to virus's spread. In addition, variant-specific boosters were being developed, with one firm claiming it could take as little three months to modify its vaccine for a particular variant and bring it to the market, thereby possibly restoring much of the initially observed effectiveness levels. ${ }^{61}$ By the standards of other similar viral vaccines, these figures were remarkably good, and they exceeded many experts' early expectations. ${ }^{62}$ Given these promising effects and the growing calamity, public-health officials were obviously eager to make the authorized vaccines widely available, and quickly. But they faced several hurdles: delays in manufacturing; transportation logistics (as some of the vaccines were required to remain at sub-zero temperatures); cost, especially for poorer countries; and, most relevant to this Article, vaccine hesitancy.

\footnotetext{
${ }^{58}$ National Center for Health Statistics, Influenza, https://www.cdc.gov/nchs/fastats/flu.htm. For a summary of the evidence on this point relying on CDC data, see Ilya Somin, Free the Vaccinated from Covid Restrictions, REASON (Apr. 7, 2021, 4:37 PM), https://reason.com/volokh/2021/05/07/free-the-vaccinated-from-covidrestrictions/.

${ }^{59}$ Jamie Lopez Bernal et al., Effectiveness of Covid-19 Vaccines Against the B.1.617.2 (Delta) Variant, 385 NEw. ENG. J. Med. 585, 594 (2021) (finding that vaccine effectiveness against the Delta variant is "modestly lower" than against the Alpha variant).

${ }^{60}$ Joe Palca, Pfizer Says a 3rd Dose of Its COVID-19 Vaccine Boosts Immunity, NPR: ALL THINGS CONSIDERED (July 28, 2021), https://www.npr.org/2021/07/28/1021892809/pfizer-says-a-3rd-dose-of-its-covid-19vaccine-boosts-immunity.

${ }^{61}$ Christiaan Hetzner, Pfizer Partner to Test COVID Vaccine Targeting Delta Variant this Month, FoRTUNE (Aug. 9, 2021), https://fortune.com/2021/08/09/covid-vaccines-delta-variant-vaccine-biontech-pfizer/ ("Germany's BioNTech believes it can switch production to combat the spread of mutations within 100 days."); Allie Hogan, Pfizer Says It Would Take This Long to Make a Delta Variant Vaccine, YAHOO (Aug. 12, 2021), https://www.yahoo.com/lifestyle/pfizer-says-long-delta-variant-123419844.html (reporting that Pfizer expects "to develop and produce a tailor-made vaccine against [the Delta] variant in approximately 100 days after a decision to do so, subject to regulatory approval"); Ron Jefferson, COVID-19 Delta Variant Vaccine May Be Developed in Just 4 Weeks or Less As BioNTech Plans Immediate Formulation, Science Times (Aug 12, 2021), https://www.sciencetimes.com/articles/32803/20210812/covid-19-delta-variant-vaccine-developed-4-weeksless-biontech.htm ("Developing a new delta variant vaccine only takes a few weeks, according to BioNTech CEO and co-founder Uğur Şahin.”).

${ }^{62}$ Helen Branswell, Comparing the Covid-19 Vaccines Developed by Pfizer, Moderna, and Johnson \& Johnson, STAT (Feb. 2, 2021), https://www.statnews.com/2021/02/02/comparing-the-covid-19-vaccines-developed-by-pfizer-moderna-andjohnson-johnson/; Carl Zimmer, 2 Companies Say Their Vaccines Are 95\% Effective. What Does That Mean?, N.Y. Times (Nov. 20, 2020), https://www.nytimes.com/2020/11/20/health/covid-vaccine-95-effective.html ("We were all expecting 50 to 70 percent." (quoting Dr. Gregory Poland, Mayo Clinic vaccine researcher)).
} 


\section{Vaccine Hesitancy}

Vaccine hesitancy is a "socio-cultural" phenomenon ${ }^{63}$ which "represents a serious threat to global health." ${ }^{64}$ The subject has produced a large body of research in immunology and other public-health fields attempting to understand why people decide to accept or reject vaccination. ${ }^{65}$ Since its introduction for smallpox in the 1700s, vaccination "has been the subject of many different controversies and vaccination scares," and the resulting vaccine hesitancy has frustrated progress in combating infectious diseases. During the American colonial period, most people refused to be inoculated against smallpox, in part out of general distrust of government authority. ${ }^{66}$ Others thought that inoculation had even more diabolical connections; in July 1772, the English minister Edmund Massey delivered a sermon in London called "The Dangerous and Sinful Practice of Inoculation."

More recently, vaccine hesitancy has contributed to the resurgence of disease outbreaks like measles and pertussis. ${ }^{68}$ The modern anti-vaccination movement gained steam in the early 2000s following a - later invalidated and retracted - study by British doctor and researcher, Andrew Wakefield, which falsely linked the measles-mumps-rubella vaccination to autism in young children. ${ }^{6}$ Hesitancy toward the COVID-19 vaccine in 2021 proved a barrier to achieving a critical mass of immunized people, such that infection cannot readily spread even among the unprotected, a phenomenon called "herd immunity."

As mentioned above, one policy response to address low vaccine uptake - whether in 1901 or 2021 - is a vaccine passport: selectively providing benefits and access to public spaces to those who are immunized against the disease. Despite the widespread coverage and strong opinions that developed about the issue, the term "vaccine passport" is not particularly well-defined in most public discourses. Below we break down the concept and explore the different ways in which vaccine passports can be implemented by governments and private organizations.

\footnotetext{
${ }^{63}$ Eve Dubé, Caroline Laberge, Maryse Guay, Paul Bramadat, Réal Roy, \& Julie A. Bettinger, Vaccine Hesitancy: An Overview, 9 Hum. VACCINES \& IMMUNOTHERAPEUTICS 1763 (2013).

${ }^{64}$ Malik Sallam, COVID-19 Vaccine Hesitancy Worldwide: A Concise Systematic Review of Vaccine Acceptance Rates, 9 VACCINES 1, 8 (2021) (summarizing survey studies).

${ }^{65}$ See generally Dubé et al., supra note 64 (noting that "since its introduction, vaccination has been the subject of many different controversies and vaccination scares").

${ }^{66}$ Geppert \& Paul, supra note 19, at 298. The smallpox inoculation at that time was not vaccination but variolation, that is, exposing the subject to a small amount of the virus itself. Edward Jenner developed the world's first vaccine decades later. See id.

${ }^{67}$ Azhar Hussain, Syed Ali, Madiha Ahmed \& Sheharyar Hussain, The Anti-vaccination Movement: A Regression in Modern Medicine, 10 CUREus (2018).

${ }^{68}$ Sallam, supra note 64 , at 8 .

${ }^{69}$ Andrew Wakefield et al., Ileal-Lymphoid-Nodular Hyperplasia, Non-specific Colitis, and Pervasive Developmental Disorder in Children, 351 LANCET 637 (1998) (paper retracted).
} 


\section{Vaccine Credentials}

The term "vaccine passport" denotes two distinct but related concepts, which are often conflated in popular discourse. ${ }^{70}$ The first means simply a credential, either paper or electronic, that shows the holder's vaccination status. We will call this a vaccination credential, denoting either a paper or electronic version. A vaccination credential may be developed and operated by a government, a private or non-profit organization, or a partnership between the two. ${ }^{71}$ The credential holder might use it to share her vaccine history with a healthcare or insurance provider, or to gain access to services and spaces reserved for the vaccinated or otherwise immune. In electronic form, a vaccine credential has recently been referred to as a digital health credential or digital health pass (DHP). ${ }^{72}$

Although DHPs as such are not yet widespread in the United States, many Americans are carrying the functional equivalent, many without realizing it. Providers and patients increasingly store their health information such as appointments, test results, and procedure records (like vaccinations) using an electronic health record (EHP). One example of an EHP is MyChart, a patient portal developed by healthcare software company, Epic, which can be accessed via a smartphone app, and is used by tens of thousands of U.S. healthcare providers to exchange information with their patients. ${ }^{73}$ Thus, anyone with a smartphone whose healthcare provider uses a patient portal effectively carries with her an electronic record of her vaccination history.

\footnotetext{
${ }^{70}$ Even before COVID-19 vaccines were available, some had proposed a form of 'immunity certificate' for those who had recovered from COVID-19 and developed sufficient antibodies. See Henry T Greely, COVID19 Immunity Certificates: Science, Ethics, Policy, and Law, 7 J.L. \& BIOSCI. 1 (2020), https://academic.oup.com/jlb/article/7/1/1saa035/5848136.

${ }^{71}$ Consider the Excelsior Pass, New York State's credential, developed by IBM. Sharon Otterman, Will the Excelsior Pass, New York's Vaccine Passport, Catch On?, N.Y. Times (June 1, 2021), https://www.nytimes.com/2021/06/01/nyregion/excelsior-pass-vaccine.html; IBM Digital Health Pass, https://www.ibm.com/products/digital-health-pass (describing the DHP as "[d]esigned to provide organizations with a smart way to bring people back to a physical location during COVID-19"); The non-profit Commons Project is developing a digital pass called CommonPass. See https://commonpass.org/ ("CommonPass enables you to document your COVID-19 status to satisfy country entry requirements while protecting your health privacy.”).

${ }_{72}$ See IBM Digital Health Pass, supra.

73 Alicia Phaneuf, Here is a List of the Best Companies Providing EHR Systems in 2020, Bus. Insider (July 17, 2020), https://www.businessinsider.com/ehr-systems-vendors.
} 
Despite potential privacy issues, ${ }^{74}$ many jurisdictions, mainly outside the United States, have embraced vaccination credentials for COVID-19. ${ }^{75}$ In February 2021, Israel rolled out its Green Pass, ${ }^{76}$ which was recognized nationwide as proof of vaccination; it was ended that June, ${ }^{77}$ after about $60 \%$ of the country had been vaccinated and new infections had reached negligible levels. ${ }^{78}$ Starting July 1, 2021, the EU Digital COVID Certificate took effect throughout the 27 European Union member states, plus Liechtenstein and Norway. The certificate is accepted as proof of vaccination, a recent negative COVID test, or sufficient immunity antibodies. ${ }^{79}$ Switzerland now has a similar credential. ${ }^{80}$ In the United States, New York State has introduced the Excelsior Pass. ${ }^{81}$

\section{E. Restriction Exemption Programs}

The second meaning of vaccine passport is the focus of this Article: a program in which governments and/or businesses lift certain restrictions for people who have been vaccinated. We will call this a restriction exemption program. While distinct concepts, an exemption program is likely to be most effective when paired with a vaccine credential; a standardized

\footnotetext{
${ }^{74}$ Although they are largely outside the scope of this Article, the possibility of electronic data breaches means that widespread use of vaccine credentials carries a set of important privacy-related legal issues. For instance, because vaccine credentials carry sensitive medical information, they are required to comply with various laws concerning medical data and privacy generally. Allison Grande, Vaccine Passport Plans Can't Ignore Web of Privacy Laws, LAw360, April 22, 2021, https://www.law360.com/articles/1377404/vaccine-passport-planscan-t-ignore-web-of-privacy-laws ("[B]usinesses need to ensure that they have consent to use the data they're collecting, that they're not using this information for purposes beyond the reason it was collected, and that they're safely and securely storing this data ...." (citing Catherine Zhu, Foley \& Lardner LLP special counsel)).

75 Dominique Soguel, Sara Miller Llana, Lenora Chu, \& Yannis-Orestis Papadimitriou, Vaccine Passports: Why Europe Loves Them and the US Loathes Them, Christian SCI. Monitor, June 11, 2021, https://www.csmonitor.com/World/Europe/2021/0611/Vaccine-passports-Why-Europe-loves-them-and-theUS-loathes-them.

${ }^{76}$ Cat Ferguson \& Joshua Mitnick, Israel's "Green Pass" is an Early Vision of How we Leave Lockdown, MIT TECH. REV., Mar. 1, 2021, https://www.technologyreview.com/2021/03/01/1020154/israels-green-pass-is-an-early-vision-of-how-weleave-lockdown/

${ }^{77}$ Einat Albin \& Aeyal Gross, First In First Out: The Rise and Fall of Israel's Green Pass, LEX-ATLAs: Covid19, June 2, 2021, https://lexatlas-c19.org/first-in-first-out-the-rise-and-fall-of-israels-green-pass/.

${ }^{78}$ On May 30, 2021, there were only five new confirmed cases countrywide. (New daily infections later increased to over 400 on average over the first week of July 2021.) Ritchie et al., supra note 44, https://ourworldindata.org/coronavirus.

${ }^{79}$ Soguel et al., supra note 75.

${ }^{80}$ Thomas Schürpf, Die EU Anerkennt das Schweizer Covid-Zertifikat - Was Bedeutet Das?, NEUE ZÜRCHER ZEITUNG, July 8, 2021, https://www.nzz.ch/schweiz/die-eu-will-die-schweizer-covid-zertifikate-anerkennenwas-bedeutet-das-ld.1634382 (title translated as "The EU recognizes the Swiss Covid certificate - what does that mean?").

${ }^{81}$ Otterman, supra note 71; see also Lev Facherm, Resistance from Health Experts and Business Owners Could Doom 'Vaccine Passports' Even Before They Launch, STAT, Apr. 1, 2021, https://www.statnews.com/2021/04/01/resistance-vaccine-passports/ ("It's impractical . . . . [The U.S.] is a nation that does not allow a national identity card. Getting compliance is going to be hard, and I think it leads to politicization.” (quoting Georges Benjamin, Executive Director, American Public Health Association)).
} 
or otherwise reliable credential reduces the risk of fraud and increases confidence in the system.

To understand vaccine passport programs' legal status, it is helpful to first understand how they can and do function in the United States and elsewhere. A vaccine passport program can take any of three forms, which can operate simultaneously: (1) directly imposed by private organizations without a government mandate; (2) directly imposed by the government; and (3) government-imposed through private organizations. Each of the forms raises different constitutional and other legal implications, so we explain each form in turn.

\section{Independently Imposed by Private Organizations}

Without a government mandate, many private organizations since the 1800 s have voluntarily chosen to require vaccinations as a condition of service or employment. ${ }^{82}$ For example, during the Smallpox outbreak, lumber yards in Maine required proof of vaccination for entry. During COVID-19, airlines like Australia's Qantas ${ }^{83}$ and numerous cruise lines ${ }^{84}$ planned to require passengers to be vaccinated, and restaurants and stores have adopted policies requiring that in-person customers entering the building be vaccinated (often, offering unvaccinated customers the alternative to wear a mask). Though many stores have not demanded documentation of vaccination, some have. In July 2021, Broadway theaters announced that shows would re-open only to the vaccinated, with exceptions only for young children, who were required to show a negative test. ${ }^{85}$ The chief motivations for businesses' adopting these policies appear to include making customers feel more comfortable (and thus attracting more of them) and protecting customers and staff. While most private vaccine passports have so far involved commercial enterprises, other types of private organizations could potentially use them as well. For example, religious institutions, charitable enterprises, and other nonprofit organizations such as universities might limit access to vaccinated people, or at least impose restrictions (such as masking) on the non-immunized.

Though New York and some other states encouraged these actions during the COVID19 pandemic, some other states - including Florida, Texas, and Montana - did the opposite, banning private businesses from discriminating based on vaccination status, including in employment. ${ }^{86}$ Florida governor Ran DeSantis justified the move, calling it "completely

\footnotetext{
82 Taylor, supra note 2.

${ }^{83}$ Covid: Vaccination Will be Required to Fly, Says Qantas Chief, BBC, Nov., 23, 2020, available at https://www.bbc.com/news/world-australia-55048438.

84 Travel + Leisure, Every Cruise Line Requiring Passengers to Be Vaccinated Before Boarding, https://www.travelandleisure.com/cruises/cruises-that-allow-vaccinated-travelers (accessed June 9, 2021).

${ }^{85}$ Michael Paulson, Broadway Audiences Will Need Proof of Vaccination and Masks, N.Y. TIMES, July 30, 2021, https://www.nytimes.com/2021/07/30/theater/broadway-audiences-vaccine-requirement.html.

${ }^{86}$ Elliott Davis, States Are Banning COVID-19 Vaccine Requirements, U.S. NEws \& WORLD REP. (Apr. 30, 2021), https://www.usnews.com/news/best-states/articles/2021-04-30/these-states-are-banning-covid-19vaccine-requirements.
} 
unacceptable" to "impose upon you the requirement that you show proof of vaccine to just simply participate in normal society." 87

\section{Directly Government-Imposed}

The second form of an exemption program is created and operated entirely by the government: municipal, state/provincial, or national. The government directly conditions participation in certain government programs or benefits (e.g., in-person public school attendance, admission into the country of non-citizens or non-residents, government employment) on immunity. Such a policy resembles those traditionally implemented by governments for other infectious diseases, such as measles, mumps, and yellow fever.

Although (as discussed below) state and federal law generally gives states the power to discriminate against the unvaccinated in providing certain services, several U.S. states rejected that authority during the COVID-19 pandemic. In early 2021, state governors in Florida, Texas, Arizona, Montana, Idaho, and Utah issued executive orders prohibiting their state or local governments from providing exemptions based on vaccination status. ${ }^{88}$ Other states, including Florida, also passed legislation doing the same. ${ }^{89}$ In stark contrast, several other jurisdictions, such as New York City and the state of California, required their own employees to be vaccinated or else undergo weekly testing. ${ }^{90}$ The U.S. Department of Veterans' Affairs similarly mandated vaccination or testing for all healthcare employees. ${ }^{91}$ In Europe, countries including Austria, Denmark, Germany, Italy, and Lithuania have imposed quarantine requirements for people entering from foreign countries, exempting the vaccinated (though sometimes those quarantine requirements are limited to entry from highrisk countries). ${ }^{92}$

\footnotetext{
${ }^{87}$ Florida Governor Ron Desantis Signs Executive Order BANNING Vaccine Passports Because They Would Create 'Two Classes Of Citizens', DAILY MAIL, Apr. 2, 2021, https://www.dailymail.co.uk/news/article9431253/Florida-governor-bans-vaccine-passports-claiming-create-two-classes-citizens.html; see also Ron DeSantis News Releases, Governor Ron DeSantis Signs Landmark Legislation to Ban Vaccine Passports and Stem Government Overreach, May 3, 2021, https://www.flgov.com/2021/05/03/governor-ron-desantis-signslandmark-legislation-to-ban-vaccine-passports-and-stem-government-overreach/.

${ }^{88}$ Bryan Schott, New Utah Law Blocks Vaccine Passports If You're on a College Campus or at a State Government Building, SALT LAKE TRIBUNE (Apr. 6, 2021), https://www.sltrib.com/news/politics/2021/04/06/new-utah-law-blocks/ (stating how Utah passed the law to block vaccine passports).

${ }^{89}$ Elliott Davis, Which States Have Banned Vaccine Passports?, U.S. News \& WorLd ReP. (June 1, 2021), //www.usnews.com/news/best-states/articles/which-states-have-banned-vaccine-passports.

90 Joan E Greve \& Dani Anguiano, California and New York City to Mandate Vaccine for Government Workers, GUARDIAN, July 26, 2021, https://www.theguardian.com/us-news/2021/jul/26/covid-california-newyork-city-department-of-veterans-affairs-vaccine-mandate.

${ }^{91}$ Office of Public and Intergovernmental Affairs, VA Mandates COVID-19 Vaccines Among Its Medical Employees Including VHA Facilities Staff, July 26, 2021, https://www.va.gov/opa/pressrel/pressrelease.cfm?id=5696.

${ }_{92}$ Poland and Switzerland require those who were in close contact with a positively tested person to quarantine, unless they show proof of vaccination or recovery from prior illness.
} 


\section{Government-Imposed Through Private Organizations}

The third form of exemption restriction program is the most potentially far-reaching and the most legally complex - as it involves both the private and public sector. A government that has imposed restrictions on business operations, such as airlines, entertainment venues, and restaurants, might loosen those restrictions by allowing those businesses to serve customers who are vaccinated or otherwise immunized. Such policies are somewhat similar to laws regulating liquor or cigarette sales to minors: businesses may sell these items, but only to customers who meet certain criteria (i.e., can prove they are old enough/immunized). One weaker version of this policy allows businesses to serve everyone but give certain benefits (e.g., dining inside, going without a mask) only to immunized customers.

While state and local governments in the United States have been reticent to take this step, several governments elsewhere have determined them to be the best course of action to fight the pandemic. Countries including Italy, Austria, Slovakia, Cyprus, and Estonia require many businesses - such as restaurants, hotels, theaters, and gyms - to require their customers to show proof of vaccination, recovery from a prior COVID-19 infection, or a recent negative test result to be allowed to serve them. France, Denmark and Greece accept only proof of vaccination, presumably to create and incentive for people to get a vaccine..$^{93}$

\section{The Constitutional Permissibility of Vaccine Passports}

In Part IV below, we develop the Article's core claim: that immunized people who present little or no danger to the public have a constitutional right to be freed from certain restrictions. But before considering whether vaccine passports are constitutionally required, we must first consider the argument - advanced by a minority of commentators - that vaccine passports are not even constitutionally permissible.

Legal experts who have considered the issue in constitutional systems around the world generally agree that vaccine passports are compatible with their respective constitutional system. ${ }^{94}$ But a few in the United States and elsewhere have argued that the passports might implicate constitutional principles protecting equity or liberty, such Substantive Due Process or Equal Protection. ${ }^{95}$ We consider these arguments below.

\footnotetext{
${ }^{93}$ In enacting a rule prohibiting nightclubs from admitting those who recovered from prior COVID-19 illness, the Austrian Ministry of Health said explicitly that it wanted to create an incentive for young people to get vaccinated.

${ }^{94}$ As to their legality in Canada, see Thomas et al., supra note 9 (concluding that "a well-designed vaccine passport regime, backed by an equitable vaccine distribution scheme, will likely withstand a Charter [of Rights and Freedoms] challenge.").

${ }^{95}$ Whether it is constitutional to restrict some people but not others based on vaccination status may depend on how the issue is framed: (1) as arbitrarily treating people differently by granting exemptions to only some (and thus an equal protection issue); or (2) as a set of restrictions on the liberty of some (a substantive due process issue). Some, like Professor Noah Feldman, have implied that the courts might see the issue primarily
} 


\section{A. The Constitutionality of Vaccine Mandates}

The idea that vaccine passports are constitutionally required in many circumstances might be a non-starter if vaccine requirements are themselves unconstitutional. In that event, vaccine passport requirements might at least be suspect under the doctrine of "unconstitutional conditions," which in many cases forbids forcing people to give up a constitutional right in exchange for some other right or privilege extended by the government. ${ }^{96}$ Fortunately, there are few constitutional constraints on vaccination requirements for dangerous contagious diseases.

In the classic and now much-cited 1905 decision in Jacobson v. Massachusetts, ${ }^{97}$ the U.S. Supreme Court upheld a state law authorizing the imposition of mandatory smallpox vaccination for nearly all residents of the city of Cambridge, Massachusetts. The Court ruled that such regulations are part of the state's "police power" and do not violate the liberty protected by the Due Process Clause of the Fourteenth Amendment. ${ }^{98}$

It has been argued that Jacobson did not really uphold a vaccine mandate, because any adult who wished to avoid it could instead pay the mandatory $\$ 5$ fine imposed by the law. ${ }^{99}$ But nothing in the reasoning of the Court relies on the seemingly small size of the fine. To the contrary, the majority emphasizes that the law in question is a "compulsory vaccination law," and that they "assume, for the purposes of the present inquiry, that its provisions require, at least as a general rule, that adults not under the guardianship and remaining within the limits of the city of Cambridge must submit to the regulation adopted by the board of health." ${ }^{100}$ These and other passages in the opinion suggest that its reasoning applies to a coercive mandate, not just a seemingly small fine. Moreover, a \$5 fine in 1905 (roughly equivalent to $\$ 150$ in today's money), was a significant penalty: about three days' pay for a worker with an average salary. ${ }^{101}$

Contrary to some assumptions, Jacobson does not give state officials a blank check to impose any and all vaccination mandates. In his majority opinion for the Court, Justice John Marshall Harlan noted that "the police power of a state . . . may be exerted in such circumstances, or by regulations so arbitrary and oppressive in particular cases, as to justify the interference of the courts to prevent wrong and oppression." ${ }^{102}$ In the particular case of vaccination, such judicial intervention would be justified in situations where a mandate is applied to a person who is "not at the time a fit subject of vaccination, or that vaccination, by reason of his then condition, would seriously impair his health, or probably cause his

\footnotetext{
as the latter, a liberty restriction. We believe that the issue is appropriately analyzed as an equal protection issue.

${ }^{96}$ For a classic overview, see Kathleen Sullivan, Unconstitutional Conditions, 102 HARV. L. REV. 1413 (1989).

${ }^{97} 197$ U.S. 11 (1905).

${ }^{98} \mathrm{Id}$. at $25-35$.

${ }^{99}$ See Josh Blackman, Jacobson v. Massachusetts did not uphold the State's Power to Mandate Vaccinations, Volokh Conspiracy, Reason (Nov. 24, 2020), https://reason.com/volokh/2020/11/24/jacobson-vmassachusetts-did-not-uphold-the-states-power-to-mandate-vaccinations/.

${ }^{100}$ Jacobson, 197 U.S. at 24-25.

${ }^{101}$ See Salaries in 1901, available at https://panam1901.org/visiting/salaries.htm.

102 Jacobson, 197 U.S. at 38.
} 
death." 103 Harlan emphasized that the Court's decision rests on the assumption that the Massachusetts law did not require vaccination in such extreme cases. ${ }^{104}$

But such extreme circumstances are likely to apply to only a tiny fraction of the population, when it comes to vaccines for measles, polio, COVID-19, or many others, where side effects are very rare. For the vast majority of the population, vaccine mandates - and vaccine passports - would not give rise to constitutional problems, unless they involve unconstitutional discrimination on the basis of suspect characteristics, such as race, sex, or religion.

As of the time of this writing (August 2021), litigation has begun over COVID-19 vaccine mandates imposed by various institutions. So far courts, have uniformly upheld vaccination requirements. Both a federal district court and the U.S. Court of Appeals for the Seventh Circuit have upheld a COVID-19 vaccination mandate for most students on campus, imposed by Indiana University. ${ }^{105}$ Similarly, a federal district court has upheld a vaccination requirement imposed on employees of a Houston hospital. ${ }^{106}$

The latter decision has only very limited application to constitutional issues, as it addressed a mandate imposed by a private employer. But Indiana University is a public institution, and both the trial and appellate decisions decisively rejected constitutional arguments against the mandate. The Seventh Circuit ruling was written by prominent conservative jurist Judge Frank Easterbrook, and joined by two other conservative judges, both appointed by Donald Trump: Judge Michael Scudder and Judge Thomas Kirsch.

Judge Easterbrook reasoned that the Indiana University case is an easier one for the government than Jacobson was, for two reasons:

First, Jacobson sustained a vaccination requirement that lacked exceptions for adults.... But Indiana University has exceptions for persons who declare vaccination incompatible with their religious beliefs and persons for whom vaccination is medically contraindicated. The problems that may arise when a state refuses to make accommodations therefore are not present in this case...

Second, Indiana does not require every adult member of the public to be vaccinated, as Massachusetts did in Jacobson. Vaccination is instead a condition of attending Indiana University. People who do not want to be vaccinated may go elsewhere. Many universities require vaccination against SARSCoV-2, but many others do not. Plaintiffs have ample educational opportunities. ${ }^{107}$

\footnotetext{
${ }^{103} I d$. at 39 .

${ }^{104} \mathrm{Id}$.

${ }^{105}$ Klaasen v. Trustees of Indiana Univ. 2021 WL 3073926 (N.D. Ind., July 18, 2021), aff' d, 2021 WL 3281209

(7th Cir. Aug. 2, 2021).

${ }^{106}$ Bridges v. Houston Methodist Hospital, 2021 WL 2399994 (S.D. Tex., June 12, 2021).

${ }^{107}$ Klaasen, 2021 WL 3281209 at *1.
} 
This reasoning would equally serve to justify a wide range of vaccination passports, so long as they too have religious and health exemptions, and are just conditions for participating in certain activities, as opposed to blanket mandates for all members of the public. Obviously, the force of the second point is weakened in situations where there are few or no alternatives to the activities unavailable to the unvaccinated.

The trial court concluded that the Indiana University mandate is subject only to "rational basis" review, though it also emphasized that "Jacobson doesn't justify blind deference to the government when it acts in the name of public health or in a pandemic," and that "the Constitution doesn't permit the government to declare a never-ending public emergency and expand its powers arbitrarily." 108 Because of the nature of the liberty infringed and the state's strong interest in limiting the spread of COVID-19, the court also rejected the plaintiff's "unconstitutional conditions" argument. ${ }^{109}$ In so doing, it distinguished the liberty right to refuse vaccination against contagious diseases that threaten the health of others, from the more robust constitutional right to refuse medical treatment that almost exclusively benefits the patient herself. ${ }^{110}$

Justice Neil Gorsuch's concurring opinion in the 2020 Catholic Diocese case suggests that he (and probably other conservatives justices) have little intention of increasing constitutional barriers to vaccination mandates. Gorsuch distinguishes the restrictions upheld in Jacobson from those subject to heightened scrutiny on multiple grounds. ${ }^{11}$ The conservative majority on the Supreme Court may, however, ultimately require exceptions for sincere religious objectors. ${ }^{12}$ But very few policymakers object to COVID-19 vaccinations on religious grounds, so this need not pose a significant constraint. ${ }^{113}$

At least under current precedent, then, there is little doubt that a wide range of vaccine mandates are constitutional. ${ }^{114}$ At the very least, there is no constitutional barrier to establishing vaccine passports in situations where doing so is itself necessary to protect constitutional rights.

\section{B. Unequal Protection of the Unvaccinated?}

Some accept the analysis above regarding the constitutionality of vaccine mandates, but nonetheless argue it is unlawful for the government to restrict some people but not others based on their vaccination status. Under U.S. law, they are essentially making an argument about unequal protection of the laws for the unvaccinated. Some discussions of this issue

\footnotetext{
${ }^{108}$ Klassen, 2021 WL 3073926 at *21-22.

${ }^{109} I d$. at $* 22-24$.

${ }^{110} \mathrm{Id}$.

${ }^{111}$ See Roman Catholic Diocese of Brooklyn v. Cuomo, 141 S. Ct. 70-71 (2020) (Gorsuch, J., concurring).

112 For discussion of this issue, see Lindsay F. Wiley \& Steve Vladeck, Why Carefully Designed Public Vaccination Mandates Can — and Should -Withstand Constitutional Challenge, LAWfare, Aug. 12, 2021, https://www.lawfareblog.com/Designed-Public-Vaccination-Mandates.

${ }^{113} \mathrm{Id}$.

${ }^{114}$ For a recent analysis reaching similar conclusions, see $i d$.
} 
paint it with too broad a brush, overlooking the fact that the laws relevant to vaccine passports' permissibility differ between the three types of restriction exemption programs set forth above: independently imposed by private organizations; directly governmentimposed; and government-imposed through private organizations. We therefore analyze each in turn.

First, though private entities' voluntarily imposing restrictions on the non-immunized does not raise constitutional issues, doing so could implicate a series of state and federal laws concerning discrimination. As a threshold matter, the private sector in the United States generally has authority to condition service for its customers and employment for its workers on vaccination. ${ }^{115}$ As to business customers, with a few exceptions, applicable U.S. state and federal law gives private businesses wide discretion over whom they serve. ${ }^{116}$ Business owners may generally turn away customers for seemingly irrational reasons, or without giving any reason at all. ${ }^{117}$ State and federal civil rights laws provide an important exception to this rule; they prohibit "places of public accommodation" (like restaurants, shops, and concert venues) from discriminating on the basis of traits like race, religion, gender, and most relevant here - disability. ${ }^{118}$ U.S. federal statutes (the Americans With Disabilities Act and Rehabilitation Act) and analogous state laws prohibit businesses from imposing rules that discriminate against customers with disabilities. ${ }^{119}$ Thus, if a potential patron had a medical condition that prevented him from getting vaccinated, he might argue that the business must accommodate his disability by allowing him some alternative means of entry. In the case of a business with a vaccination rule, the reasonable accommodation might include wearing a mask or showing a recent negative COVID test. The business would need to accommodate this request only if the requested accommodation were "reasonable" and did not "fundamentally alter" the offered service, and if his disability did not constitute a "direct threat" to customers or employees. ${ }^{120}$

\footnotetext{
${ }^{115}$ Dylan Housman, Is It Legal For Businesses to Require Customers to be Vaccinated?, DAILY CALLER, June 10, 2021, https://dailycaller.com/2021/06/10/vaccine-passport-foo-fighters-legal-ban ("Many legal experts agree: it's almost certainly legal for most private businesses to turn away customers based on their vaccination status.").

116 See, e.g., Aaron v. Ward, 96 N.E. 736, 737 (N.Y. 1911) (holding that the "keepers of public places of amusement and resort" are entitled to "discriminate and serve whom [they] please[]"); see also Nan D. Hunter, Accommodating the Public Sphere: Beyond the Market Model, 85 MinN. L. ReV. 1591 (2001) ("The accepted starting point in examining public accommodations law is the principle that under common law, business owners have a property right to refuse service unless they are innkeepers, common carriers, or public utilities"). 117 See, e.g., Bowlin v. Lyon, 25 N.W. 766, 768 (Iowa 1885) (holding that the general right to refuse entry would apply even if the business excluded a patron "on account of the cut of his coat or the color of his hair" or if a business excluded a patron "without assigning any reason for their action").

118 See, e.g., 42 U.S.C. § 2000a (1994); Ill. Comp. Stat. Ann. 5/5-102 (1993); N.Y. Exec. Law § 296(2); see also Lisa Gabrielle Lerman \& Annette K. Sanderson, Discrimination in Access to Public Places: A Survey of State and Federal Public Accommodations Laws, 7 N.Y.U. Rev. L. \& Soc. ChAnge 215, 242-43 (1978).

11942 U.S.C. § 12182(a); 29 U.S.C. § 794; see also Alex Long, State Anti-discrimination Law as a Model for Amending the Americans with Disabilities Act, 65 U. PITT. L. REV. 597, 601-02 (2004) (discussing generally the broad landscape of state antidiscrimination laws in the disabilities context).

12042 U.S.C. § 12182(b)(2)(A)(ii); Lentini v. Cal. Ctr. for the Arts, 370 F.3d 837, 844 (9th Cir. 2004).
} 
The law also generally permits U.S. employers to require their employees to be vaccinated as a condition of keeping their jobs. ${ }^{121}$ As with business customers, some employees may be able to receive exemptions because of, e.g., a vaccine-preventing disability or religious objection. ${ }^{122}$ Second, as just discussed, the government has a similar authority as the private sector to impose a form of mandate directly on its own employees and public-school students as a condition of working or attending public school. Indeed, today all fifty U.S. states require vaccination of children attending public school, and most states also mandate vaccination of health care employees. ${ }^{123}$ Subject again to disability exemptions, those who opt against vaccination can be turned away or fired. ${ }^{124}$ When the government discriminates in this way, however, it raises potential issues under the Equal Protection Clause of the Fourteenth Amendment, which we address in more detail below.

Perhaps the most complex legal issues are raised when the government imposes a system of restriction exemption through private businesses and organizations. Under current law, state and local governments in the United States have broad power to regulate how and whom businesses serve, especially for regulations designed to achieve public-health goals. ${ }^{125}$ The government can prohibit businesses from providing services to certain people: e.g., people under 21-years-old (bars and liquors stores), or felons (gun shops). ${ }^{126}$ In addition, the government has the power to order certain businesses to close for certain periods. For instance, local health authorities can shut down businesses that fail to meet health-code standards, and, in the face of natural (or man-made) disasters, state governors sometimes institute curfews or order many businesses to close temporarily. ${ }^{127}$ During COVID-19, most state and local governments ordered at least some businesses, like bars, restaurants, and concert venues, to close, to restrict their hours, or to otherwise curtail their operations. ${ }^{128}$

${ }^{121}$ U.S. Equal Employment Opportunity Commission, EEOC Issues Updated COVID-19 Technical Assistance (May 28, 2021), https://www.eeoc.gov/newsroom/eeoc-issues-updated-covid-19-technical-assistance (concluding that federal equal employment opportunity laws "do not prevent an employer from requiring all employees physically entering the workplace to be vaccinated for COVID-19, so long as employers comply with the reasonable accommodation provisions").

${ }^{122} I d$.

${ }^{123}$ Lyndsey B. Davis, Who's Calling the Shots? Individual v. State: A Look Inside the Exemption Laws and the Threats of Foregoing Vaccinations, 21 SUfFOLK J. TRIAL \& APP. ADVOC. 372, 380 (2016).

${ }^{124}$ Religious-based exemptions are legally required for employees but likely not for students. See Phillips, 775 F.3d at 543 (holding that although "New York could constitutionally require that all children be vaccinated in order to attend public school," "New York law goes beyond what the Constitution requires by allowing an exemption for parents with genuine and sincere religious beliefs.").

125 Elizabeth Joh, Yes, States and Local Governments Can Close Private Businesses and Restrict Your Movement, Politico, Mar. 18, 2020 (observing that "State and local governments can indeed decide to force even unwilling businesses to shut down," but that "[a]t some point in the future, we could see a coronavirus response that has gone on too long or is too broad to justify its burdens").

126 See, e.g., Indigo Room, Inc. v. City of Fort Myers, 710 F.3d 1294 (11th Cir. 2013) (upholding a city ordinance prohibiting persons younger than 21 from entering bars); United States v. Inglese, 282 F.3d 528 (7th Cir. 2002) (holding that gun shop owners are required to prevent purchases by convicted felons).

127 See Smith v. Avino, 91 F.3d 105 (11th Cir. 1996) (upholding curfew order issued during hurricane), abrogated on other grounds by Steel Co. v. Citizens for a Better Environment, 523 U.S. 83, 94 (1998).

128 Erin Schumaker, Here Are the States that have Shut Down Nonessential Businesses, ABC News (Apr. 3, 2020), https://abcnews.go.com/Health/states-shut-essential-businesses-map/story (noting that "[a]t least 46 states" have enacted measures to "close nonessential businesses"). 
Although there were exceptional cases where restrictive orders violated separation-ofpowers principles or undermined constitutional rights, most COVID-19 restrictions were broadly considered constitutional and otherwise lawful, given that no better alternative apparently existed for slowing the outbreak. ${ }^{129}$

Given these broad existing powers, ${ }^{130}$ it might seem to follow naturally ${ }^{131}$ that governments can lawfully tailor their pandemic restrictions to prohibit businesses and organizations from serving customers who pose greater danger to public health. The greater power to force businesses to close entirely for certain periods, the argument goes, includes the lesser power to force businesses to close to some people for a time. The issue is not quite this straightforward, however. Generally speaking, this "greater includes the lesser" logic does not always apply when it involves the government treating people differently. For example, the fact that the government could constitutionally prohibit everyone from buying marijuana does not imply that it may constitutionally, say, allow only Asian people to buy marijuana. In these cases, the group subject to the restriction may raise a claim under the principle of equal protection of the laws.

In general, where a plaintiff claims that the government has unlawfully treated him worse than others - an alleged violation of Equal Protection principles - the first step of the analysis is determining the basis for the distinction the government is making. Where it is based on some "suspect" classification, like race or religion, the court uses strict scrutiny (whether it is "narrowly tailored"/uses the "least restrictive means" to achieve a "compelling government interest"). ${ }^{132}$ Where the distinction is not based on a classification that is suspect, nor on sex/gender or illegitimacy, courts use rational basis analysis (whether it is "rationally related" to a "legitimate government interest"). ${ }^{133}$ This initial classification is partly a function of voluntariness. The protected classes are traits that are either immutable, i.e., cannot be changed, or those that a liberal government has no right to force the person to change, like her religion. The bases analyzed under rational basis analysis are often (not always) traits that are acquired voluntarily or more easily changeable, such as mental disability ${ }^{134}$ or company nationality ${ }^{135}$ Specifically, a suspect class constitutes: (1) "an immutable characteristic"; which is (2) "irrelevant to a legitimate legislative generalization"; that is (3) "used to disadvantage a politically powerless group."136

129 See, e.g., Talleywhacker, Inc. v. Cooper, 465 F. Supp. 3d 523, 537-38 (E.D.N.C. 2020) (upholding restrictions forcing widespread business closures); Altman v. Cnty. of Santa Clara, 464 F. Supp. 3d. 1106, 1121 (N.D. Cal. 2020) (upholding shelter-in-place orders); Antietam Battlefield KOA v. Hogan, 461 F.3d 214, 231 (D. Md. 2020) (upholding order limiting in-person gatherings). But see Roman Cath. Diocese of Brooklyn v. Cuomo, 141 S. Ct. 63, 69 (2020) (enjoining enforcement of COVID-19 restrictions on religious services).

130 Jacobson, 197 U.S. at 11 (noting that the "legislature is primarily the judge" for determining what ought to be done to protect against "an epidemic of disease"); Marshall v. United States, 94 S. Ct. 706 (1974) (holding that when governments act "in areas fraught with medical and scientific uncertainties" they enjoy "especially broad" latitude).

${ }^{131}$ That is, with the exception of the disability-related issues mentioned above.

132 See City of Cleburne v. Cleburne Living Ctr., 473 U.S. 432, 439-41 (1985).

133 Id. at 442.

${ }^{134}$ See Heller v. Doe, 509 U.S. 312 (1993).

${ }^{135}$ See Metropolitan Life Ins. Co. v. Ward, 105 S. Ct. 1676 (1985).

${ }^{136}$ Frontiero v. Richardson, 411 U.S. 677 (1973). 
As discussed above, given the widespread availability of the COVID-19 vaccine in many countries, being unvaccinated for residents of those countries is usually voluntary. Even where the vaccine is not yet available to a person because she is younger, healthier, or otherwise at low risk, the trait of non-immunization is still not immutable, as she is likely to become eligible in the near future. Were a currently non-immunized person to challenge the COVID-19 restrictions imposed on her pursuant to an exemption program, a court would therefore apply only rational basis analysis. She would face the high burden of needing to show that the distinction is not rationally related to any legitimate government interest.

She would surely be unable to do so. A person's decision to not be vaccinated imposes costs on herself. But, as elaborated in Part V.A. below, it also imposes negative externalities on society. First, even though some vaccines may prevent symptomatic infection at levels reaching, say, $95 \%,{ }^{137}$ that means that about $5 \%$ of symptomatic disease is not prevented relative to the unvaccinated. A person who is not vaccinated puts even the vaccinated at a small risk of themselves becoming infected. Though the risk of contracting disease is small for any vaccinated individual, if hundreds of millions of individuals are routinely exposed to unvaccinated individuals, many - perhaps many thousands - additional people will be infected, and, though the great majority will have few or no symptoms, some fraction of those could suffer severe side effects or even death. Second, when the unvaccinated transmit the virus to others, who are usually themselves non-immunized, the pandemic is prolonged, increasing the likelihood that more-dangerous variants will develop. It is possible that existing COVID-19 vaccines will be less effective against future variants, putting even the vaccinated at more serious risk, at least until additional, variant-specific booster vaccines are developed and disbursed.

Given these objectives, a non-immunized plaintiff would certainly be unable to show that preventing the non-immunized from accessing certain public spaces is not rationally related to the legitimate government interest of protecting the public from the pandemic. Though the methods of analysis may differ, there appears to be a near consensus among legal experts about this conclusion. ${ }^{138}$

\section{VACCINE PASSPORTS AS A CONSTITUTIONAL Right}

The fact that governments may constitutionally require private businesses and their own agencies to serve only immunized customers does not imply a far more contentious claim:

137 Science Brief: COVID-19 Vaccines and Vaccination, CDC (July 27, 2021), https://www.cdc.gov/coronavirus/2019-ncov/science/science-briefs/fully-vaccinated-people.html (noting that "[a]ll authorized vaccines demonstrated efficacy" up to "95\% . . . against symptomatic" COVID-19 infection).

138 See Noah Feldman, This Supreme Court Isn't Going to Like Vaccine Passports, BloomBERG (Apr. 13, 2021), https://www.bloomberg.com/opinion/articles/2021-04-13/are-vaccine-passports-legal-supreme-courtand-law-scholars-may-disagree (noting that "[t]he consensus among legal experts seems to be that states have the right to mandate vaccine passports," but arguing that "we should not assume that this deference to state power would continue under the current Supreme Court"). 
that they sometimes must do so. The rest of this Article, however, considers just that proposition.

The U.S. Constitution recognizes a wide range of rights: to bear arms, to just compensation when certain regulations severely diminish property value, and to freedom of movement and travel, for instance. When the government regulates in these areas, it is generally bound to do so in ways that do not unduly infringe on constitutionally protected rights and freedoms. The Constitution does not require the government to use its regulatory authority. But we argue that, where certain public-health restrictions are in place, the government - given certain assumptions - is obligated to exempt the vaccinated, in effect creating a form of vaccine passport program.

This is true despite the tradition of judicial deference to the political branches during times of crisis. ${ }^{139}$ Traditional arguments against giving the government a judicial blank check in other types of emergencies - such as threats from crime or terrorism - also apply in a pandemic context. ${ }^{140}$ Giving pandemic emergency measures a general exemption from normal judicial scrutiny might allow governments to push through overreaching measures under a public-health justification. Relying on the political process alone to check abusive pandemic emergency policies is unlikely to be sufficient, given the danger of panic and irrationality on the part of voters, and widespread voter ignorance and partisan bias, which make it difficult for voters to effectively evaluate policies - especially those responding to novel emergencies with which they are unfamiliar. ${ }^{141}$

In the sub-parts that follow, we analyze the constitutional rights to interstate travel; intrastate (i.e., local) travel; international travel; compensation for regulatory takings via business closures; abortion; the right to bear arms; and freedom of assembly and worship each in the context of pandemic-related restrictions. Each of these rights may empower plaintiffs to challenge public-health restrictions that fail to exempt the vaccinated.

\footnotetext{
139 See generally Eric A. Posner \& Adrian Vermeule, Terror in the Balance: SeCURITy, Liberty, AND the Courts (2007); Eric A. Posner \& Adrian Vermeule, The Executive Unbound: After the MADISONIAN REPUBLIC (2011)

${ }^{140}$ For more detailed discussion of these issues, see Lindsay F. Wiley \& Stephen I. Vladeck, Coronavirus, Civil Liberties, and the Courts: The Case Against "Suspending” Judicial Review, 133 HARV. L. REV. F. 1 (2020); Ilya Somin, The Case for "Regular" Judicial Review of Coronavirus Emergency Policies, The Volokh Conspiracy, REASON (Apr. 15, 2020, 4:16 PM), https://reason.com/2020/04/15/the-case-for-normal-judicialreview-of-coronavirus-emergencypolicies; Tom Ginsburg \& Mila Versteeg, The Bound Executive: Emergency Powers During The Pandemic, _ INT’L J. Con. L. _ (2021).

${ }^{141}$ For a more detailed discussion of how political ignorance and bias undermine effective democratic accountability and strengthen the case for judicial review, see Ilya Somin, DEMOCRACY AND POLITICAL IGNORANCE: WHY SMALLER GOVERNMENT IS SMARTER, chs. 2, 6 (rev. ed. 2016).
} 


\section{A. Domestic Movement and Travel Under Fourteenth Amendment Substantive Due Process}

\section{Interstate Travel}

The Supreme Court has long held that there is a constitutional right to interstate travel, going back to before the enactment of the Fourteenth Amendment. In the 1867 case of Crandall v. Nevada, the Court struck down a state law imposing an exit tax on people leaving the state, because - it concluded - interstate travel is a right built into the structure of the Constitution. ${ }^{142}$ As Justice Samuel Miller put it in his opinion for a unanimous Court, "We are all citizens of the United States, and as members of the same community must have the right to pass and repass through every part of it without interruption, as freely as in our own states." 143

More recently, the Court has held that this right is embedded in the Equal Protection Clause and Privileges or Immunities Clause of the Fourteenth Amendment, and extends even to barring state laws that discriminate against new residents in the provision of welfare benefits. ${ }^{144}$ In Saenz v. Roe (1999), the Court explained that the right to interstate travel "embraces at least three different components,' including "the right of a citizen of one State to enter and to leave another State, the right to be treated as a welcome visitor rather than an unfriendly alien when temporarily present in the second State, and, for those travelers who elect to become permanent residents, the right to be treated like other citizens of that State." 145

The Supreme Court has never clearly specified what level of scrutiny applies to laws violating the right to interstate travel. However, it has indicated that such infringements can be upheld only if they have a "compelling justification," and analogized such cases to situations where regulations restrict a "fundamental" right, and are therefore subject to strict scrutiny. ${ }^{146} \mathrm{At}$ the very least, therefore, infringements of the right to travel should be subject to a much higher level of scrutiny than minimal "rational basis."

During the COVID-19 pandemic, numerous states enacted restrictions on interstate travel, most typically requiring entrants from states with relatively high infection rates to quarantine for a 14-day period. ${ }^{147}$ In a May 2020 decision, a federal district court ruled that Maine's 14-day quarantine regulation for visitors from high-infection states must be subject to strict scrutiny, but also refused to issue a preliminary injunction barring the quarantine restriction, because it might well pass strict scrutiny, given the seriousness of the pandemic,

\footnotetext{
${ }^{142}$ Crandall v. Nevada, 73 U.S. 35 (1867).

${ }^{143}$ Id. at 49 (quoting Passenger Cases, 48 U.S. 283, 492 (1849) (Grier, J., dissenting).

${ }^{144}$ See Shapiro v. Thompson 394 U.S. 618 (1969) (Equal Protection Clause protects such a right); Saenz v. Roe, 526 U.S. 489 (1999) (Privileges or Immunities Clause).

${ }^{145}$ Saenz, 526 U.S. at 500.

${ }^{146}$ See Attorney General of NY v. Soto-Lopez, 476 U.S. 898, 904 (1986).

${ }^{147}$ For an overview of such restrictions, Laurie Baratti, "COVID-19 in September: Which US States Have Travel Restrictions?," TRAVEL PULSE (Sept. 2, 2020), https://www.travelpulse.com/news/impactingtravel/covid-19-in-september-which-us-states-have-travel-restrictions.html
} 
and the supposed lack of effective less-restrictive means of limiting its spread. ${ }^{148} \mathrm{~A}$ different district court upheld a similar New York quarantine restriction on the grounds that the Supreme Court's famous 1905 ruling in Jacobson v. Massachusetts - upholding a smallpox vaccination requirement - required a generally low level of scrutiny of pandemic-related measures. ${ }^{149}$

However, as mentioned above in the discussion of vaccine mandates' constitutionality, the Supreme Court has since repudiated this broad interpretation of Jacobson, making it clear that it does not apply to infringements of constitutional rights subject to heightened scrutiny. ${ }^{150}$ In his concurring opinion in Roman Catholic Diocese v. Cuomo, Justice Gorsuch emphasized several key distinctions between Jacobson and regulations restricting rights protected by heightened scrutiny, including the low level of scrutiny the court applied in the former case, and the nature of the rights in question. ${ }^{151}$ While the majority's and Gorsuch's analysis focused on the Free Exercise Clause of the First Amendment, the same logic applies to other constitutional rights protected by heightened scrutiny.

Assuming that pandemic restrictions on the right to interstate travel are indeed subject to some form of heightened scrutiny, there is a strong case for the idea that vaccinated travelers have a constitutional right to be exempted from state quarantines and other restrictions on the right to interstate movement. As discussed earlier, vaccinated individuals have a 3-8 times lower chance of being infected by COVID-19 - including the more contagious Delta variant - and therefore a far lower chance of spreading it to others. If this risk is nonetheless enough to overcome heightened scrutiny, it would justify a near-total gutting of the right to travel, since restrictions could also be imposed to prevent the spread of the flu, and other "normal" diseases that pose comparable dangers to that created by vaccinated individuals.

Moreover, under any heightened scrutiny framework, vaccination qualifies as a lessrestrictive alternative to a 14-day quarantine, since it reduces the risk of spreading the disease by at least as much. ${ }^{152}$ As the court pointed out in the 2020 Maine Bayley's Campground case, a universal 14-day quarantine requirement "effectively closes the border for many would-be travelers." 153 A vaccination exemption greatly reduces the number of people for whom this would be true. For many others, it at least offers an easy way to avoid the problem, by getting vaccinated themselves.

\footnotetext{
${ }^{148}$ Bayley's Campground, Inc. v. Mills, 463 F. Supp. 3d 22 (D. Maine, 2020), aff'd, 985 F.3d 153 (1st Cir. 2021). The appellate ruling in the case did not consider the issue of standard of review, because it concluded that the quarantine order was constitutional even under strict scrutiny. Id. at 159-61.

${ }_{149}$ Page v. Cuomo, 478 F.Supp.3d 355 (N.D. N.Y. 2020) (citing Jacobson v. Massachusetts, 197 U.S. 11 (1905)).

${ }^{150}$ See Roman Catholic Diocese of Brooklyn v. Cuomo, 141 S. Ct. 63, 67 (2020) (emphasizing that "even in a pandemic, the Constitution cannot be put away and forgotten," and that, before allowing restrictions on fundamental rights to go forward, courts "have a duty to conduct a serious examination of the need for such a drastic measure").

${ }^{151} \mathrm{Id}$. at 70-71 (Gorsuch, J., concurring).

${ }^{152}$ See Bayley's Campground, 463 F. Supp. 3d at 34-35 (discussing the relevance of less restrictive alternatives in the strict scrutiny context for travel restrictions).

${ }^{153} I d$. at 34 .
} 
In sum, even in cases where pandemic-related restrictions on interstate travel might otherwise withstand constitutional scrutiny, there must be exemptions for the vaccinated. Otherwise, the restrictions in question would violate the right to travel, and must be struck down by courts.

As of this writing, quarantine requirements for interstate travel within the United States have been largely repealed. However, there is a chance they might be used again in the future, either to combat new upsurges of COVID-19 or to address other disease risks. When and if such policies are adopted in the future, they too must include exemptions for the vaccinated, if effective vaccines are available.

\section{Intrastate Travel}

As early as March 2020, most jurisdictions throughout the United States imposed some form of local travel restrictions on their residents. By April 1, 2020, at least 38 states and territories, 74 counties, and 15 cities, had issued some form of stay-at-home-orders. ${ }^{154}$ In the most extreme, residents were not permitted to leave their residences except for a limited set of enumerated, "essential" purposes like work, food shopping, and caregiving. As the pandemic raged on, some jurisdictions developed more elaborate rules on who could travel for what purpose. How strictly the stay-at-home orders were enforced varied greatly by jurisdiction, ranging from no enforcement to heavy use of citations or, rarely, jail. ${ }^{155}$

Local travel restrictions were equally or more severe in some other countries, and they continued much longer in some places, even well after vaccines were widely available. In July 2021, some states in Australia like New South Wales and Victoria re-imposed lockdowns; citizens were not permitted to leave their residences except for certain approved reasons like shopping or exercise, and even then, could not travel more than 5-10 kilometers from their residences or leave their local government area, ${ }^{156}$ even though new case rates in Australia were then about four per one-million people per day, about 1/40 of the case-rate then present in Europe. ${ }^{157}$

\footnotetext{
${ }^{154}$ Betsy Pearl, Lea Hunter, Kenny Lo, \& Ed Chung, The Enforcement of COVID-19 Stay-at-Home Orders, CENTER FOR AM. PROGRess (Apr. 2, 2020), https://www.americanprogress.org/issues/criminaljustice/news/2020/04/02/482558/enforcement-covid-19-stay-home-orders.

${ }^{155}$ See Stephanie Farr, N.J. has Charged More Than 1,700 for Violating Stay-At-Home Orders but Just a Handful of Citations Have Been Issued in Pa., PHIL. INQUIRER (Apr 21, 2020), https://www.inquirer.com/news/coronavirus-stay-at-home-orders-violations-pennsylvania-philadelphia-newjersey-police-enforcement-20200421.html (noting that a 54-year-old homeowner hosting a gathering was "just one of more than 1,700 people charged with breaking the stay-at-home order in New Jersey" over a three-week period in March and April 2020); Yvianna Davila \& Ren Larson, South Texas Restrictions were Meant to Protect People From COVID-19. Then the Handcuffs and Ticket Books Came Out, TEXAS TRIBUNE \& PropubliCA (Dec. 19, 2020), https://www.texastribune.org/2020/12/19/coronavirus-south-texas-enforcement. ${ }_{156}$ Victoria Covid Lockdown Restrictions: Latest Update to Melbourne and Regional Vic Coronavirus Mask Rules Explained, GUARDIAN (July 15, 2021), https://www.theguardian.com/australianews/2021/jul/16/victoria-lockdown-melbourne-covid-restrictions-coronavirus-new-rules-latest-updatecovid19-explained-5km-radius-travel-face-masks-compulsory-exercising-home-gatherings-intimate-partnerwhat-you-need-to-know.

${ }^{157}$ Ritchie et al., supra note 44, https://ourworldindata.org/coronavirus.
} 
While constitutional doctrines on the rights to interstate travel are fairly well-developed, the constitutional right to intrastate or local travel is more nascent. The U.S. Supreme Court has implied the existence of a fundamental right to movement generally. The Court noted in 1920 in United States v. Wheeler that U.S. state citizens had always "possessed the fundamental right, inherent in citizens of all free governments, peacefully to dwell within the limits of their respective states, to move at will from place to place therein, and to have free ingress thereto and egress therefrom." 158 But the Court has never fully fleshed out the contours of such a right. ${ }^{159}$

Several federal courts of appeals have, however, with most recognizing some constitutional right to movement or local travel rooted in substantive due process. ${ }^{160}$ For instance, in a case challenging the constitutionality of an anti-car-cruising ordinance, ${ }^{161}$ the Third Circuit held in 1990 that "the right to move freely about one's neighborhood or town, even by automobile, is indeed 'implicit in the concept of ordered liberty' and 'deeply rooted in the Nation's history." ${ }_{162}$ The court applied intermediate scrutiny, analogizing to freeexpression time, place, or manner restrictions. The test was therefore whether the law was "narrowly tailored to meet significant city objectives." 163 It concluded that it was, because it found the cruising policy in that case was narrowly tailored to address the city's welldocumented safety concerns. ${ }^{164}$ Likewise, the Second Circuit in King v. New Rochelle Municipal Housing Authority concluded that "[i]t would be meaningless ... to describe the right to travel between states as a fundamental precept of personal liberty and not to acknowledge a correlative constitutional right to travel within a state." ${ }^{165}$ The King court invalidated a requirement that did not outright ban inter-city travel, but penalized those who had not lived in the city for five years by disqualifying them from eligibility for public housing. ${ }^{166}$ The Sixth Circuit also recognizes that the "right to travel locally through public spaces and roadways" 167 is fundamental and subjects such restrictions to strict scrutiny. ${ }^{168}$ In Cole v. City of Memphis, the Sixth Circuit enjoined the defendant city from enforcing its

\footnotetext{
${ }^{158}$ United States v. Wheeler, 254 U.S. 281, 293 (1920).

${ }^{159}$ See Williams v. Fears, 179 U.S. 270 (1900) ("[T] he right of locomotion, the right to remove from one place to another according to inclination, is an attribute of liberty ... secured by the 14th amendment.") Though, as a Lochner-era case, the Williams Court thought similarly about the right to contract, id. at 271 ("[S]o as to the right to contract"), so the continuing validity of its view on the right to movement may be dubious.

${ }^{160}$ See Lutz v. City of York, 899 F.2d 255 (3d Cir. 1990); King v. New Rochelle Municipal Housing Authority, 442 F.2d 646 (2d Cir.), cert. denied, 404 U.S. 863, 92 S. Ct. 113, 30 L.Ed.2d 107 (1971); Catron v. City of St. Petersburg, 658 F.3d 1260 (11th Cir. 2011); Doe v. City of Lafayette, 377 F.3d 757 (7th Cir. 2004).

${ }^{161}$ The ordinance prohibited repeatedly circling certain streets in a car during evening hours. Lutz, 899 F.2d at $256-57$.

${ }^{162}$ Id. at 267-68 (holding that, even assuming a narrow (i.e., Scalia-like) notion of substantive due process, it would "reject [the city's] argument that the Due Process Clause does not substantively protect a right to intrastate travel").

${ }^{163} I d$. at 270 .

${ }^{164} \mathrm{Id}$.

${ }^{165}$ King v. New Rochelle Municipal Housing Authority, 442 F.2d 646, 648 (2d Cir.), cert. denied, 404 U.S. 863, 92 S. Ct. 113, 30 L.Ed.2d 107 (1971).

${ }^{166}$ King, 442 F.2d at 648.

167 Johnson v. City of Cincinnati, 310 F.3d 484, 495 (6th Cir. 2002).

${ }^{168}$ Cole v. City of Memphis, 839 F.3d 530, 534 (6th Cir. 2016).
} 
"policy, procedure, custom, or practice by which police officers . . . order all persons to immediately leave the sidewalks and street . . . without consideration of whether conditions throughout the ... area pose an existing, imminent or immediate threat to public safety." 169 A series of other holdings from other circuits, including the Seventh and Eleventh, also implies some freedom of local movement, though they suggest that that right is not fundamental. ${ }^{170}$ In contrast, the Tenth Circuit is unique in holding that "the fundamental right to freedom of movement applies 'only to interstate travel.", 171

The majority view among the circuits recognizes some right to local movement or travel. In at least some jurisdictions, such travel restrictions in the context of public safety must be justified by an "existing, imminent[,] or immediate threat to public safety" and/or be "narrowly tailored" to the government's significant safety concerns.

In light of this precedent, how should a U.S. court evaluate a ban on local travel similar to New South Wales's July 2021 COVID-19 travel restrictions, which applies explicitly to people immunized with a highly effective vaccine? Before the development and disbursement of effective vaccines, a number of challenges were mounted in the United States against COVID-19 stay-at-home orders and travel bans. Some succeeded, and others were unsuccessful. ${ }^{172}$ Some of the courts in those cases determined that, given the potentially deadly risks of close proximity, orders prohibiting certain types of travel were a rational policy response.

The availability of effective vaccines changes this calculus. As the Sixth Circuit stated in the intrastate travel case, Johnson v. City of Cincinnati, "if there are other, reasonable ways to achieve [its] goals with a lesser burden on constitutionally protected activity, a State may not choose the way of greater interference. If it acts at all, it must choose 'less drastic means." 173 When restricting only the non-immunized from traveling would accomplish the government's objectives, doing so would indeed exert "a lesser burden on constitutionally protected activity." In cases like measles in the 2010s, or COVID-19 in summer 2021, in which severe symptomatic cases were "almost exclusively" among the unvaccinated, ${ }^{174}$

\footnotetext{
${ }^{169} I d$.

${ }^{170}$ Catron v. City of St. Petersburg, 658 F.3d 1260, 1266 (11th Cir. 2011) (holding that "[p]laintiffs have a constitutionally protected liberty interest to be in parks or on other city lands of their choosing that are open to the public generally," but not considering whether that right is fundamental); Doe v. City of Lafayette, 377 F.3d 757, 769-70 (7th Cir. 2004) (acknowledging the constitutional right "to enter the parks to loiter or for other innocent purposes" but holding that the right is not fundamental).

${ }^{171}$ McCraw v. City of Oklahoma City, 973 F.3d 1057, 1081 (10th Cir. 2020) (quoting D.L. v. Unified Sch. Dist. No. 497, 596 F.3d 768, 776 (10th Cir. 2010)).

${ }^{172}$ Brandy v. Villanueva, 2:20-cv-02874, at 6-7 (N.D. Cal. Nov. 19, 2020) (holding that "a five-day closure of non-essential businesses, including firearms and ammunition retailers, reasonably fits the County's stated objectives of reducing the spread of this disease").

173310 F.3d 484, 503 (6th Cir. 2002) (quoting Dunn v. Blumstein, 405 U.S. 330, 343 (1972)).

174 Dan Keating \& Leslie Shapiro, For Unvaccinated, Coronavirus is Soaring Again, WASH. Post (July 21, 2021), https://www.washingtonpost.com/health/interactive/2021/unvaccinated-case-rate-delta-surge/ ("The people who need to come to hospital, who end up in the intensive care unit, and the people who die are almost exclusively unvaccinated individuals" (quoting William Powderly, director of the Institute for Public Health at Washington University in St. Louis)).
} 
restricting both the immunized and non-immunized is "the way of greater interference" with little or no policy advantage. A court following this rule should invalidate such a restriction.

\section{B. International Travel}

As discussed, international vaccine passports were a centerpiece in the policy response to previous epidemics, including polio, smallpox, and yellow fever. After effective vaccines were developed for each of those diseases, many countries began requiring proof of vaccination to enter.

In 2021, several countries have already implemented vaccine passports, requiring proof of COVID-19 vaccination for admission. ${ }^{175}$ In most countries, however, restrictions on international travel were implemented without regard to vaccination or immunization status. As of early July 2021, even vaccinated citizens of the EU were not permitted to enter the United States. Most non-citizens were barred from entering Australia, Japan, or Argentina, among other countries. In some places such as Australia, even citizens and permanent residents have been barred from exiting, even to visit family abroad. ${ }^{176}$ Policies like this have indefinitely separated families; kept people from their homes; threatened the livelihoods of those who depend on foreign business; and caused countless missed births, weddings, and funerals of loved ones.

What does the U.S. Constitution say about the validity of these types of policies? In the United States and many other countries, courts give the executive branch wide discretion in the area of immigration, especially when national security or public health is at stake. ${ }^{177}$ One of us has criticized double standards that exempt immigration restrictions from many constitutional restrictions that apply to other government policies, ${ }^{178}$ and argued for a presumption of freedom of movement in international migration. ${ }^{179}$ But it seems unlikely that courts will radically restrict federal government power over immigration in the near future. It is therefore extremely unlikely that U.S. courts would overrule an executive order closing the borders to non-citizens from certain countries that the president has determined to present a health risk. This is true, even though a reliably verifiable vaccine passport (such as EU's Digital COVID Certificate) would arguably screen-out risky customers more accurately than categorical entry bans applied to entire nations. That said, many of the same

175 See Covid Passports: How Do They Work around the World?, BBC News (Jul. 26, 2021), https://www.bbc.com/news/world-europe-56522408.

${ }^{176}$ Sowaibah Hanifie, Heartbreak for Thousands of Australian Residents Banned From Reuniting With Their Foreign Parents, ABC NEws (Apr 21, 2021) https:/www.abc.net.au/news/2021-04-22/covid-stopsaustralians-from-reuniting-with-overseas-parents/100081730.

${ }^{177}$ Cf. Trump v. Hawaii, No. 17-965, 585 U.S. __ (2018) (holding that a president proclamation banning entry of nationals from certain Muslim-majority countries neither exceeded president's statutory authority nor violated the Establishment Clause).

178 See Ilya Somin, Immigration Law Defies the American Constitution, ATlantic (Oct. 3, 2019), https://www.theatlantic.com/ideas/archive/2019/10/us-immigration-laws-unconstitutional-double-

standards/599140/.

${ }^{179}$ See Ilya Somin, Free to Move: Foot Voting, Migration, and Political Freedom chs. 3, 5-6 (2020). 
principles discussed above also apply to the case of immigration, and policymakers would do well to consider the arguments made here in formulating COVID-19 border policies.

As with traditional travel passports and visas, vaccine passports would serve as a substitute for complete border closings, admitting only those whom the state has determined present no threat. Indeed, opening the doors to the vaccinated (who, as with their visa status, would be required to prove their vaccination status before boarding the plane) would not increase the risk to residents of the host country, especially if the policy were paired with rapid COVID tests administered upon arrival at passport control. A policy of allowing free entry to vaccinated people and those willing to accept vaccination at the border, as a condition of entry, may well actually contain the spread of disease more effectively than categorical entry bans, which incentivize illegal migration, and also create a risk of spreading disease in immigration detention facilities.

Moreover, if courts or other branches of government reconsider and pare back legal doctrines exempting immigration restrictions from conventional constitutional constraints, vaccine passports might become constitutionally required in this area of policy, as well. For example, passports could serve as an alternative to blanket exclusion of travelers and migrants based on national origin, a form of discrimination currently permitted with respect to migration restrictions, but subject to strict scrutiny in other contexts. ${ }^{180}$

\section{Challenges to Shutdowns Under the Fifth Amendment Takings Clause}

From early on in the COVID crisis, numerous state and local governments imposed shutdown orders and capacity limitations on a variety of businesses and other institutions. ${ }^{181}$ In many situations, these shutdown orders imposed severe costs on the owners of affected businesses and other institutions. For obvious reasons, businesses such as restaurants or movie theaters that cannot serve patrons in person or can only do at a fraction of their usual capacity face high costs and may even end up shutting down completely. ${ }^{182}$ Civil society organizations and houses of worship may be unable to effectively provide services to their constituencies.

Affected businesses and other institutions filed a number of lawsuits challenging COVID shutdown orders and occupancy restrictions under the Takings Clause of the Fifth Amendment, and similar provisions in state constitutions, requiring payment "just

\footnotetext{
${ }^{180}$ Indeed, national origin discrimination is forbidden even in the immigration context, when engaged in by state governments, as opposed to the federal government. See, e.g., Exodus Refugee Immigration v. Pence, 165 F.Supp. 3d 718 (S.D. Ind. 2016), aff'd 838 F.3d 902 (7th Cir. 2016) (striking down state government nationalorigin restriction on refugee resettlement).

${ }^{181}$ Hannah Miller, Reopening America: A State-by-State Breakdown of the Status of Coronavirus Restrictions, CNBC (Apr. 30, 2021), https://www.cnbc.com/2020/04/30/coronavirus-states-lifting-stay-at-home-ordersreopening-businesses.html (listing covid restrictions in all states).

182 See, e.g., Davide Scigliuzzo, Josh Saul, Shannon D. Harrington, Claire Boston, \& Demetrios Pogkas, The Covid Bankruptcies: Guitar Center to Youfit, BloOMBerg (Dec. 31, 2020), https://www.bloomberg.com/graphics/2020-us-bankruptcies-coronavirus/ (listing businesses that went bankrupt during the Covid crisis, in part because of shutdown orders).
} 
compensation" in situations where the government takes private property. ${ }^{183}$ The issues raised by these cases have not gotten as much scrutiny as those raised by other challenges to COVID shutdown orders. But they deserve careful consideration because of the immense costs inflicted on property owners and others. Should some shutdown orders qualify as takings, that could potentially require the government to pay extensive compensation, and create a strong incentive to limit the scope of shutdown restrictions.

So far, courts have rejected takings challenges to shutdowns, based in large part on the "police power" exception to the Takings Clause, which is understood to exempt some government actions from takings liability if they serve police power purposes of protecting public health and safety. The most significant decisions of this type are rulings by the state supreme courts of New Mexico and Pennsylvania. ${ }^{184}$ The New Mexico ruling was based solely on the state constitution's Takings Clause, but relied heavily on federal precedent. ${ }^{185}$ The Pennsylvania decision addressed both the federal and state takings clauses, but used federal precedent to determine the scope of both. ${ }^{186}$

These cases were all decided with respect to shutdown orders imposed before vaccination became available on a mass scale. Thus, they did not address the issue of whether the police power exception applies even to shutdowns of businesses and other institutions that adopt vaccine passports: limiting entry to employees and patrons who have been vaccinated. Previous scholarship on takings challenges to COVID shutdown orders likewise does not address the significance of the vaccination issue. ${ }^{187}$

There is strong reason to believe that COVID shutdown orders that cover establishments using vaccine passports fall outside the scope of any plausible police power exception. They therefore require payment of compensation in any situation where the restrictions in question are onerous enough to require compensation under ordinary takings jurisprudence.

The scope of the police power exception to takings liability is far from clear, and has long been a focus of intense debate. ${ }^{188}$ Outside the context of the COVID crisis, courts have in recent years issued somewhat contradictory decisions in this field. ${ }^{189}$ For example, the U.S. Court of Federal Claims recently held that the police power exception does not apply in a situation where the U.S. Army Corps of Engineers deliberately flooded thousands of homes and businesses in Houston in order to forestall even greater flooding elsewhere during

\footnotetext{
${ }^{183}$ U.S. CONST. amend. V.

${ }^{184}$ For the most prominent such cases, see Friends of Danny DeVito v. Wolf, 227 A.3d 872 (Pa. 2020) and New Mexico v. Wilson, 2021 WL 2310061 at *9-14 (N.M., June 7, 2021).

${ }^{185}$ Wilson, 2021 WL 2310061 at *9-14.

${ }^{186}$ Friends of Danny DeVito, 227 A.3d at 893-97.

187 See, e.g., Shai Stern, Taking Emergencies Seriously, URBAN LAWYER (forthcoming, 2021), available at https://papers.ssrn.com/sol3/papers.cfm?abstract id=3632203; Robert H. Thomas, Evaluating Emergency Takings: Flattening the Economic Curve, 29 WM. \& MARY BILL OF RighTs J. 1145 (2021); Shelley Ross Saxer, Necessity Exceptions to Takings, HAWAII L. REV. (forthcoming), available at https://papers.ssrn.com/sol3/papers.cfm?abstract id=3811090; F.E. Guerra-Pujol, The Law of Self-Ownership (unpublished manuscript), available at https://papers.ssrn.com/sol3/papers.cfm?abstract id=3567003.

${ }^{188}$ For overviews, see, e.g., D. Benjamin Barros, The Police Power and the Takings Clause, 58 MiAmI L. REv. 471 (2004); Joseph L. Sax, Takings and the Police Power, 74 YALE L.J. 36 (1964).

${ }^{189}$ For a detailed overview of relevant cases, see Saxer, supra note 187, at 21-49.
} 
Hurricane Harvey in 2017. ${ }^{190}$ By contrast, in 2019, the Tenth Circuit ruled that the police power exception does apply in a case where police almost completely destroyed an innocent family's house in the process of using grenades and other weapons to apprehend a suspect shoplifter who had holed up in the building. ${ }^{191}$

We do not attempt here to resolve the broader general debate over the scope of police power exceptions to takings. Rather, we contend that shutdown orders applied to enterprises that use vaccine passports must fall outside any defensible theory of the scope of that exception. If they do not, almost all government seizure, occupation, and regulation of property rights would fall within the scope of the police power exception, thereby essentially gutting the Takings Clause.

As discussed earlier in this Article, ${ }^{192}$ it appears that fully vaccinated individuals face only a miniscule risk of contracting a serious case of COVID-19 themselves and a very reduced risk of transmitting the virus to other vaccinated people. The risk that a fully immunized person falls severely ill after infecting herself through another fully vaccinated person is exceedingly small. Even non-immunized people are 3-8 times less likely to contract COVID-19 from a vaccinated person than an unvaccinated one, because the former is relatively unlikely to get even asymptomatically infected, even by the Delta variant. A business or other enterprise that effectively imposes vaccine passport requirements for entry thereby creates only a miniscule potential danger. Miniscule, of course, is not zero. But if mitigating such a tiny risk puts restrictions on such businesses within the police power exception, the same justification applies to almost all other government seizures, occupations, and shutdowns of private property.

Many decisions finding that a "regulatory" or physical taking has occurred require compensation even in situations where the government was acting to mitigate a risk to health or safety considerably greater than that posed by establishments with fully vaccinated customers and staff. The 1922 case of Pennsylvania Coal Co. v. Mahon, in which the U.S. Supreme Court first recognized that regulations that do not involve physical invasion of property can be takings if they go "too far," concerned restrictions on mining intended to protect buildings on the surface from collapse. ${ }^{193}$ The recent Houston hurricane flood case likewise involved efforts to limit flooding that poses a serious risk of harm to life and property.

The same is true of numerous other cases involving both regulatory takings and physical destruction of property by the government. ${ }^{194}$ Indeed, it would even apply to traditional acquisitions of property for various public works, using the power of eminent domain. For

\footnotetext{
${ }^{190}$ In re Upstream Addicks and Barker (Tex). Flood Control Reservoirs, 146 Fed. Cl. 219 (Ct. Claims 2019). The same court later refused to allow takings liability in "downstream" cases arising from the same policy. But that was because the plaintiffs could not prove that the damage to their property was caused by the Army Corps of Engineers' actions, not because of the police power exception. See In re Downstream Addicks and Barker (Tex). Flood Control Reservoirs, 147 Fed. Cl. 566 (Ct. Claims 2020).

${ }^{191}$ Lech v. Jackson, 791 Fed. Appx. 711 (10th Cir. 2019).

193260 U.S. 393, 415 (1922).

${ }^{194}$ For a more extensive listing, see Sax, supra note 185.
} 
example, building a new road might make driving significantly safer relative to previously available roads in the area, thereby greatly reducing traffic fatalities. Sometimes, the difference in safety between possible routes might even be quite large. If so, under the same logic justifying lockdowns for establishments using vaccine passports, this could potentially qualify under the police power exception, and thereby justify seizing the property without compensation.

In a classic 1964 article on takings and the police power, Professor Joseph Sax suggested that the police power exception should apply anytime the government is acting as an "arbiter" between competing private interests in regulating property, as opposed to seizing and using land for itself (or for a specific private party). ${ }^{195}$ This approach would, presumably, make almost any COVID restrictions non-compensable, so long as the state could argue that its shutdown orders were benefiting other private parties in the area. But it would have the same effect on nearly all other regulatory takings, and physical invasions that destroy property without actually occupying it. So long as the government could claim that other property owners and private interests in the areas benefit from the restrictions or destruction, it would be non-compensable.

Such an approach would require overruling numerous Supreme Court and other takings precedents, many of which deal with cases where the government imposes burdens on some property owners in order to potentially benefit others. In almost any case where authorities impose regulatory restrictions or physical invasions of private property, it can be argued that these actions are beneficial to private parties in the area. For example, laws requiring owners to allow public access to beach front property - ruled to be takings by the Supreme Court surely benefit those who have gained access. ${ }^{196}$ The Court's recent decision holding that a Californian law requiring agricultural growers to grant regular access to their property to union organizers qualifies as a taking, would also be wrong under this standard, since the law clearly benefited another private party: the union organizers. ${ }^{197}$

Similar problems arise from the New Mexico Supreme Court's June 2021 ruling holding COVID shutdown restrictions fall under the police power exception if "as an exercise of the State's police power [they] are reasonably related to their stated purpose" of protecting public health; in that event, "the purpose may be determinative of insulation from takings analysis," unless the regulations in question completely destroy all economic value, as in the Supreme Court's 1992 ruling in Lucas South Carolina Coastal Council. ${ }^{198}$

The court did not make clear exactly how high a burden of proof must be met before the government can demonstrate that its regulations are "reasonable." But it did conclude that "Given the contagious nature of the disease and considering current information, including

195 Sax, supra note 185.

196 See Nollan v. Calif. Coastal Comm'n, 483 U.S. 825 (1987); Dolan v. City of Tigard, 512 U.S. 374 (1994).

${ }^{197}$ Cedar Point Nursery v. Hassid, 141 S. Ct. 2063 (2021). For an early analysis of this decision, see Ilya Somin, Supreme Court's Cedar Point Property Rights Decision Protects Both Sides, THE HiLL (June 23, 2021), available at Supreme Court's Cedar Point Property Rights Decision Protects Both Sides," The Hill (June 23), 2021.

198 Wilson, 2021 WL 2310061 at *9 (citing Lucas v. S. Carolina Coastal Council, 505 U.S. 1003, 1027-30 (1992)). 
the promise of vaccines and the concerns of variants, the [Public Health Orders] efforts to reduce the spread of the disease continue to be reasonably related to the public health emergency" and that "the means of the PHOs' restrictions are reasonably necessary for the accomplishment of reducing the transmission of the disease."199

Despite the mention of the "promise of vaccines," the New Mexico decision had no occasion to confront situations where the businesses in question made use of vaccine passports. But if the "reasonableness" standard is so deferential that even regulations imposed on a business restricted to vaccinated customers automatically fall within the police power exception, that exception would swallow the rule, much like under the Sax approach. Shutting down or restricting almost any business or other private organization could plausibly be argued to reduce the spread of at least some dangerous diseases or reduce at least some sort of threat to public safety. For example, every year thousands of Americans die of the flu; shutting down businesses or imposing occupancy limits on them could potentially stop its spread, thereby removing risks comparable or greater than those posed by the spread of COVID-19 by and among vaccinated customers. ${ }^{200}$

Even if the police power exception does not apply to COVID regulations constraining institutions that use vaccine passports, many such restrictions might still not qualify as takings. Under current Supreme Court precedent, some types of government infringements on property are considered "per se" (automatic) takings. These include regulations that impose permanent physical occupations of property, ${ }^{201}$ regulations that destroy all economic value, ${ }^{202}$ and - most recently - those that impose even temporary physical occupations. ${ }^{203}$

Most other regulatory and physical takings claims, however, remain subject to the complex and confusing three-part balancing test established in the Court's 1978 Penn Central decision. ${ }^{204}$ The three factors are: "[t]he economic impact of the regulation on the claimant," the "extent to which the regulation has interfered with distinct investment-backed expectations," and the "character of the government action." 205 The Penn Central decision has been much criticized for vagueness, and arguably excessive deference to the government. ${ }^{206}$

But so long as it remains on the books, at least some COVID-related restrictions on businesses with vaccine passports are likely to be upheld under its three-part balancing test. In its decision upholding pre-vaccination COVID shutdown orders against challenge, the Pennsylvania Supreme Court relied not only on the police power theory, but also on Tahoe-

\footnotetext{
${ }^{199} I d$. at *10 (quotations omitted).

${ }^{200} \mathrm{Cf}$. Somin, Free the Vaccinated (citing relevant data on flu deaths).

${ }^{201}$ See Loretto v. Teleprompter CATV Corp., 458 U.S. 419, 426 (1982).

${ }^{202}$ Lucas v. S. Carolina Coastal Council, 505 U.S. 1003, 1015 (1992).

${ }^{203}$ Cedar Point Nursery v. Hassid, 141 S. Ct. 2063 (2021).

${ }^{204}$ Penn Central Transp. Co. v. City of New York, 438 U.S. 104 (1978).

${ }^{205} \mathrm{Id}$. at 123 .

${ }^{206}$ For extensive citations to such criticisms, see David Callies, Regulatory Takings and the Supreme Court, 28 Stetson L. Rev. 523, 523 n. 1 (1999). Cf. Eric R. Claeys, The Penn Central Test and Tensions in Liberal Property Theory, 30 HARV. ENV. L. REV. 339, 340, 344 (2006) (arguing that the majority of the Court's justices apply the Penn Central test in a way that is generally deferential to the government and noting that the "conventional wisdom" among "land-use lawyers" interprets the Court's application of the test that way).
} 
Sierra Preservation Council, Inc. v. Tahoe Regional Planning Agency, a 2002 Supreme Court ruling applying the Penn Central framework to justify upholding the order. ${ }^{207}$ It concluded there was no taking under that theory because the shutdown order imposed only a "temporary" closure of the plaintiffs' businesses, and therefore did not qualify as a per se taking or as a regulatory taking under Penn Central. ${ }^{208}$ In Tahoe-Sierra, the majority ruled that prolonged, but "temporary" moratorium on development does not qualify as a per se taking, and is therefore subject to the Penn Central framework. ${ }^{209}$ Similarly, in the Pennsylvania case, the majority emphasized that "the public health rationale for imposing the restrictions in the Executive Order, to suppress the spread of the virus throughout the Commonwealth, is a stop-gap measure and, by definition, temporary." 210

In a partial dissent joined by two other justices, Chief Justice Saylor pointed out that "[w]hile the majority repeatedly stresses that such closure is temporary..., this may in fact not be so for businesses that are unable to endure the associated revenue losses." ${ }^{211}$ When and if a similar case reaches the federal Supreme Court, it is possible that Saylor's position might be endorsed by a majority of justices.

Interestingly, among the factors the majority cited as indicating the "temporary" nature of the shutdown were that "the development of a vaccine to prevent future outbreaks, the development of an immunity in individuals previously infected and the availability of widespread testing and contact tracing are all viewed as the basis for ending the COVID-19 disaster." 212 This suggests that, under the court's logic, the ruling might have gone the other way if similar shutdown measures were imposed even after the availability of a vaccine perhaps especially if the targeted businesses made use of vaccine passports.

The effects of Penn Central on COVID takings litigation might also change if the federal Supreme Court further reduces the range of cases that fall within its scope. Recently, the Supreme Court held that government regulations that impose temporary occupations of property are per se takings, and thereby not subject to the Penn Central framework. ${ }^{213}$ While it is unlikely that Penn Central will be overruled completely, it could be further eroded at the margin.

We do not try to further assess the ongoing debate over Penn Central and its future. We make only the more modest points that COVID-related restrictions on property rights should not fall within the police power exception to takings liability if the institutions in question utilize vaccine passports. In addition, we emphasize that, if the police power theory is rejected, some COVID shutdown orders and other restrictions might well qualify as either per se takings, or ones that require liability under Penn Central. At the very least, they should

${ }^{207}$ Friends of Danny DeVito, 227 A.3d at 894-96 (relying on Tahoe-Sierra Pres. Council, Inc. v. Tahoe Reg'1 Planning Agency, 535 U.S. 302 (2002)).

${ }^{208}$ Friends of Danny DeVito, 227 A.3d at 894-96.

${ }^{209}$ Tahoe-Sierra, 535 U.S. at 316-33.

${ }^{210}$ Friends of Danny DeVito, 227 A.3d at 896.

${ }^{211} \mathrm{Id}$. at 904 (Saylor, C.J., dissenting).

${ }^{212} I d$. at 896.

${ }^{213}$ Cedar Point, 141 S.Ct. at 2609-18. 
be assessed under the same standards that apply to other takings claims, rather than given any kind of blanket immunity to takings liability.

\section{Abortion Under the Constitutional Right to Privacy}

In March and April 2020, a number of U.S. states effectively suspended nearly all abortion procedures by classifying them as non-essential or elective medical procedures, and thus subject to statewide moratoria on such procedures. ${ }^{214}$ Many of these orders were challenged in federal court, leading to a series of injunctions that restored access to abortions on at least a case-by-case basis. ${ }^{215}$ United Nations officials said the abortion restrictions violated human rights. ${ }^{216}$

Under current Supreme Court precedent, an abortion restriction is unconstitutional if it imposes an "undue burden" on a woman seeking an abortion because its "purpose or effect" is to "place a substantial obstacle in the path of a woman seeking an abortion before the fetus attains viability." 217 Courts undertaking this analysis must consider "the burdens a law imposes on abortion access together with the benefits those laws confer."218

In one case from Alabama, the state justified imposing these restrictions to free medical resources for COVID-19 patients, as well as to prevent the spread of COVID-19 from patient-to-staff contact. ${ }^{219}$ The district court found that the evidence did not support the resource arguments.

To the extent these restrictions did not impose undue burdens on abortions when they were issued in early 2020, they would certainly do so if they were re-imposed indiscriminately after vaccines were introduced. Even if the restrictions once served a valid medical purpose by reducing transmission between unvaccinated patients and medical staff (a questionable proposition), such benefit would be de minimis as applied to the fully vaccinated.

\footnotetext{
${ }^{214}$ Laurie Sobel, Amrutha Ramaswamy, Brittni Frederiksen, \& Alina Salganicoff, State Action to Limit Abortion Access During the COVID-19 Pandemic, KFF (Aug. 10, 2020), https://www.kff.org/coronaviruscovid-19/issue-brief/state-action-to-limit-abortion-access-during-the-covid-19-pandemic/.

215 E.g., Robinson v. Marshall, No. 2:19-CV-365 MHT (M.D. Al. Apr. 12, 2020) https://www.aclualabama.org/sites/default/files/field_documents/138_preliminary_injunction.pdf; see also Sobel et al., supra note 214.

${ }^{216}$ UN Experts Say U.S. Abortion Restrictions During COVID-19 Crisis Violate Human Rights, CENTER FOR REPRODUCTIVE RigHTS, Sept. 8, 2020, https://reproductiverights.org/un-experts-say-u-s-abortion-restrictionsduring-covid-19-crisis-violate-human-rights/ (claiming that a number of states "seem to have been manipulating the crisis to severely restrict women's reproductive rights" (quoting UN Working Group on Discrimination against Women and Girls, May 22, 2020, https://spcommreports.ohchr.org/TMResultsBase/DownLoadPublicCommunicationFile?gId=25279)).

${ }^{217}$ Planned Parenthood of Se. Penn. v. Casey, 505 U.S. 833, 878 (1992) (plurality opinion).

${ }^{218}$ Whole Woman's Health v. Hellerstedt, 136 S. Ct. 2292, 2309 (2016).

219 Robinson v. Harris, No. 20-11401-B (11th Cir. Apr. 23, 2020), https://s3.documentcloud.org/documents/6876558/4-23-20-11th-Circuit-Opinion-Robinson.pdf.
} 
Obviously, critics of Roe v. Wade $e^{220}$ and its progeny have long argued that these decisions are wrong, and that there is no constitutional right to abortion. If they are correct, there is no constitutional requirement to exempt the vaccinated from public health restrictions that constrain abortion access. But to the extent that there is a constitutional right to abortion entitled to significant judicial protection, such exemptions are required for measures that might be permissible if applied to the unvaccinated.

\section{E. Lockdown Restrictions on the Second Amendment Right to Bear Arms}

Early in the COVID-19 pandemic, state lockdown orders shutting down "nonessential" businesses impacted gun stores in many states. ${ }^{221}$ This led to litigation challenging such restrictions on the grounds that they violate the Second Amendment right to "keep and bear arms." 222

In two major decisions, the Supreme Court has recognized that the Second Amendment protects an individual right (and not simply a right of the states to establish militias), ${ }^{223}$ and that the right applies against state and local governments, not just the federal government. ${ }^{224}$ However, the Court was far from clear on the exact scope of Second Amendment rights, or the level of review that applies.

In 2020, two district court rulings upheld state shutdown orders requiring gun stores to close because of their "nonessential" nature. ${ }^{25}$ The two decisions applied relatively deferential standards of review. One decision held that the government's policies need only have a "reasonable fit" to combatting the spread of COVID-19 (in one case). ${ }^{226}$ The other applied heightened intermediate scrutiny but - somewhat inconsistently - refused to "second-guess" the state's rationale for classifying gun stores as "nonessential," even as it allowed many other stores to remain open. ${ }^{227}$ Professor Josh Blackman has criticized these decisions as excessively deferential, for failing to carefully probe the state's reasons for treating gun stores differently from many other businesses. ${ }^{228}$

For our purposes, the key point to note is that both rulings were issued before COVID19 vaccines became available, and thus neither considered the possibility of exempting the vaccinated. To the extent that the right to bear arms is indeed an individual constitutional right that extends to the purchase and sale of firearms, as well as mere possession, public health shutdown orders are constitutionally required to exempt gun stores that limit access

\footnotetext{
220410 U.S. 113 (2021).

${ }^{221}$ For an overview of such restrictions, see Josh Blackman, The "Essential" Second Amendment, TEX. REV. L. \& PoL. (forthcoming), available at https://papers.ssrn.com/sol3/papers.cfm?abstract id=3827441.

${ }^{222}$ U.S. CONST., amend. II.

${ }^{223}$ District of Columbia v. Heller, 554 U.S. 570 (2008).

${ }^{224}$ McDonald v. City of Chicago, 561 U.S. 742 (2010).

${ }^{225}$ See Dark Storm Indus. LLC v. Cuomo, 471 F. Supp. 3d 482, 504 (N.D.N.Y. 2020); Altman v. Cty. of Santa Clara, No. 20-CV-02180-JST, 2020 WL 2850291, at *13 (N.D. Cal. June 2, 2020)

${ }^{226}$ Altman, at *16.

227 Dark Storm, 471 F. Supp. at 499-505.

${ }^{228}$ Blackman, supra note 221, at 27-32.
} 
to the vaccinated, even in cases where those orders might be valid as applied to businesses with unvaccinated customers and employees.

As with the right to abortion, discussed above, this point need not be accepted by those who believe there is no constitutional right at stake here in the first place. They might reach that conclusion either by arguing that the Second Amendment does not protect an individual right to possess arms at all, ${ }^{229}$ or because they think that right does not include a right to purchase and sell firearms, as opposed to merely possess them.

\section{F. Restrictions on Assembly and Religious Gatherings Under the First Amendment}

No type of challenge to COVID-19 public health restrictions has attracted as much attention and litigation as claims of violations of First Amendment rights to freedom of speech and free exercise of religion. The Supreme Court has decided multiple Free Exercise Clause cases alone, ${ }^{230}$ and there have also been numerous lower court rulings on the subject. ${ }^{231}$ Most of these cases involved claims that COVID shutdown orders discriminated against in-person religious services, forcing them to shut down, even as other types of public gatherings were allowed to remain open. While less numerous and less hotly debated than Free Exercise Clause claims, there have also been a number of cases where courts considered (and mostly rejected) First Amendment freedom of assembly and association challenges to COVID restrictions. ${ }^{232}$

We cannot here address the extensive debate to which these cases have given rise. But we will briefly explain how they fit in to our basic framework. First, in some instances courts have struck down the application of public health restrictions on First Amendment grounds regardless of the vaccination status of the people involved. This is particularly true of two prominent Supreme Court decisions involving Free Exercise Clause challenges. ${ }^{233}$ Our analysis is irrelevant to such cases.

Unlike many other forms of constitutionally protected activities, religion is quintessentially practiced in groups, with the faithful often in close proximity to each other. For infectious diseases, religious practitioners are thus often easy victims. For the same reason, public-health restrictions that prevent large-group gatherings, like those challenged during the COVID-19 pandemic, disproportionately affect the practice of religion, even where the restriction does not intentionally or explicitly target it.

\footnotetext{
${ }^{229}$ See, e.g., Michael A. Waldman, The Second Amendment: A Biography (2014).

${ }^{230}$ See Tandon v. Newsom, 141 S. Ct. 1294 (2021); Roman Catholic Diocese of Brooklyn v. Cuomo, 141 S. Ct. 63 (2020); Calvary Chapel v. Sisolak, 140 S.Ct. 2603 (2020); South Bay United Pentecostal Church v. Newsom, 140 S.Ct. 1613 (2020).

${ }^{231}$ For a detailed overview of litigation in this field, see Josh Blackman, The "Essential" Free Exercise Clause, 4 HARV. J.L. \& PUB. POL'Y 637 (2021).

${ }^{232}$ See, e.g., Beahn v. Gayles, 2021 WL 3172272 (S.D. Md. July 26, 2021); Calm Ventures, LLC v. Newsom, 2021 WL 1502657 (C.D. Cal. Mar. 25, 2021).

${ }^{233}$ See, e.g., Tandon v. Newsom, 141 S. Ct. 1294 (2021); Roman Catholic Diocese of Brooklyn v. Cuomo, 141 S. Ct. 63 (2020).
} 
Under current precedent, a plaintiff bringing a Free Exercise case must generally show that a challenged law displays animus or otherwise discriminates against religion. Under the Supreme Court's decision in Employment Division v. Smith (1990), the Free Exercise Clause is not violated where "prohibiting the exercise of religion is not the object [of the law,] but merely the incidental effect of a generally applicable and otherwise valid provision." ${ }^{234}$ Thus, it would seem that a religious practitioner denied the opportunity to engage in group services who challenged the law would face a high hurdle, unless the law specifically singled out religious practice. While some of the COVID-19 restrictions did so, ${ }^{235}$ many applied to group gatherings generally.

There is some reason to believe, however, that the foundations of the holding in Employment Division are on shaky ground. In Employment Division, four justices - one concurring and three dissenting - would have used a compelling interest test in challenges to a "neutral law of general applicability" that nonetheless burdens religion. ${ }^{236}$ Thirty-one years later, in Fulton $v$. City of Philadelphia (2021) ${ }^{237}$ some of the justices seemed willing to adopt this rule. In a concurrence joined by two other justices, Justice Alito wrote that he would overrule Employment Division. He would replace its holding with the following rule: "A law that imposes a substantial burden on religious exercise can be sustained only if it is narrowly tailored to serve a compelling government interest." ${ }^{238}$ In essence, the concurring justices joining Alito's opinion, would use strict scrutiny in cases like these. Some believe that this view could gain support from the majority of the Court; as Berkeley School of Law Dean Erwin Chemerinsky and UC Irvine Chancellor Howard Gillman wrote, "The conservative justices on the current Court reject Scalia's reasoning [in Employment Division] and may be about to overrule [it]." 239

Even if Smith is overruled, the resulting decision might not end up imposing strict scrutiny on all regulations that burden religious liberty. Justice Amy Coney Barrett's concurring opinion in Fulton, joined by Justice Brett Kavanaugh, indicates that she is "skeptical about swapping Smith's categorical antidiscrimination approach for an equally categorical strict scrutiny regime." ${ }^{240}$ Still, it is likely that a reversal of Smith would lead to at least some form of heightened scrutiny for most laws burdening religious liberty.

Before vaccines were available, generally applicable limits on gatherings that applied to indoor religious gatherings were arguably narrowly tailored. Especially in an activity that often involves singing in close proximity, it was unclear if other measures, like masking,

\footnotetext{
${ }^{234} 494$ U.S. 872, 885 (1990).

${ }^{235}$ E.g., Roman Catholic Diocese of Brooklyn, 141 S. Ct. at 63.

236494 U.S. at 885.

${ }^{237} 141$ S. Ct. 1868 (2021) (Alito, J., concurring).

${ }^{238} \mathrm{Id}$. at 1868 .

${ }^{239}$ Howard Gillman \& Erwin Chemerinsky, The Weaponization of the Free-Exercise Clause, ATLANTIC (Sept. 18, 2020), https://www.theatlantic.com/ideas/archive/2020/09/weaponization-free-exercise-clause/616373/ ("The conservative justices on the current Court reject Scalia's reasoning and may be about to overrule Employment Division v. Smith.").

${ }^{240}$ Id. at 1883 (Barrett, J., concurring).
} 
would effectively prevent transmission. But as with the fundamental rights cases discussed above, where a public-health restriction must be narrowly tailored, the government would face a much more difficult challenge justifying a restriction that prohibited religious gatherings for the vaccinated. Given the extreme rarity of vaccinated-to-vaccinated transmission, courts might look skeptically on such broad gathering bans, when other, more targeted measures would likely be similarly effective.

\section{The ETHICS OF DisCRIMINATION ON THE BASIS OF VACCINATION STATUS}

One purpose of constitutionalism is to establish a set of lofty normative principles around which a society is organized and which guide government action. For instance, the U.S. Constitution is generally thought to embody the structural principles of limited government and federalism, as well as individual liberal values such as free expression and due process. ${ }^{241}$ Nonetheless, some argue that the principles chosen for constitutionalization often reflect the drafters' personal values or interests more than universal ones, or at least not those of the entire polity. Relatedly, in attempting to develop just and ethical laws, both constitutional drafters and those who interpret those provisions often err, sometimes badly. Indeed, the principle of inequality was arguably codified in elements of the original 1787 U.S. Constitution. ${ }^{242}$ As a result, there sometimes exists a gulf between what constitutional law dictates and what notions of justice, ethics, or the public interest demand.

Thus, the fact that existing constitutional law may require the government to exempt vaccinated or otherwise immunized people from many restrictions does not establish conclusively that it would be right to do so. At the same time, law and ethics are not wholly separate domains; courts conducting constitutional analysis, especially on novel constitutional questions, often consider the ethics and policy of the legal rules they propose to develop. We therefore next consider the ethics of discriminating on the basis of vaccination status, drawing on a variety of normative political theories concerning liberty, efficiency, fairness, and equality. ${ }^{243}$ Specifically, we analyze the following ethical considerations: fair allocation of costs; individual liberty; discrimination and social stratification; and disparate impact on ethnic groups.

\footnotetext{
${ }^{241}$ J.L. Hill, The Five Faces of Freedom in American Political and Constitutional Thought, 45 B.C.L. REV. 499, 504-05 (2004) (arguing that "the fabric of constitutional tradition" includes the values of limited government and free expression).

${ }^{242}$ See U.S. CONST. art. I sec. 2 (stating that representation and taxes shall be apportioned among the states by their "adding to the whole number of free persons ... three fifths of all other Persons [(enslaved people)]"). During Reconstruction, the Thirteenth and Fourteenth Amendments partially remedied that, outlawing slavery, and enshrining the principle of equal protection of the laws, respectively. Id. amend. XIII, XIV.

${ }^{243} C f$. Netta Barak-Corren, David Enoch, David Heyd, Ofer Malcai, \& Michal Shur-Ofry, Personal Decisions, Public Consequences: On Distinguishing Between the Vaccinated and the Non-Vaccinated in Coronavirus Management, Hebrew University of Jerusalem Legal Studies Research Paper Series No. 21-6, Mar. 1, 2021, https://papers.ssrn.com/sol3/papers.cfm?abstract id $=3793188$.
} 


\section{A. Fair Allocation of Costs and Incentivizing Vaccination}

According to many strains of liberal political theory, the main valid justification for restricting people's civil liberties is that their actions impose costs on others. ${ }^{244}$ Not being immune during an epidemic (whether or not by choice) imposes clear costs on the nonimmunized person: namely, increased risk of illness and death. But it also imposes costs on others, assuming the non-immunized person does not impose a strict self-quarantine ${ }^{245}$ or other extraordinary measure to avoid infecting others.

In economic terms, these external costs are called externalities. Those externalities stem from the greatly increased risk of becoming infected, which could result in four main effects: (1) unwittingly transmitting the virus to others, saddling them with the risk of death or the other effects of the illness; (2) directly consuming public health resources, like hospital beds other medical resources, thereby potentially denying them to others; (3) forcing increased public expenditures on resources to address the epidemic, which are paid by members of the public generally; and (4) prolonging the epidemic, which is likely to extend the period of restrictions and allow time for more aggressive, more-vaccine-resistant mutations.

In almost every infectious-disease epidemic, there is an initial period in which vaccines are not yet available. In many cases, imposing appropriate restrictions on everybody might be justified during that period. The availability of safe, effective vaccines changes this calculus. As a thought experiment, imagine that a vaccine were $100 \%$ effective both in preventing severe disease and in transmitting the disease to others. In this case, the vaccinated would generate no negative externalities on others. The unvaccinated, on the other hand, would create two forms of negative externalities: transmitting the disease to other unvaccinated people; and consuming scarce medical resources. These two might justify leaving restrictions in place for the unvaccinated, though the unvaccinated could argue that they are only endangering themselves and other unvaccinated people. Given that we might say that these unvaccinated voluntarily "assumed the risk" (to borrow a concept from the law of torts) of contracting a severe illness, the externality of increased probability of illness is therefore not relevant. Given that the scenario of reaching high vaccination rates, especially among the most vulnerable, seemed realistic, the prospects of overburdening the medical system seemed rather remote. A policy to restrict the unvaccinated would therefore largely rest on paternalistic grounds: protecting the unvaccinated from the consequences of their own decisions. While paternalism is considered a valid ground for government coercion under some schools of political theory, it is generally considered a weaker basis than the liberal principle of preventing harm to others. ${ }^{246}$

Consider how this logic applies to the COVID-19 pandemic. In early 2021, some vaccines showed effectiveness levels that, while not $100 \%$ as in the hypothetical scenario

\footnotetext{
${ }^{244}$ See John StUART MiLl, On LiBerTy 103 (1859) (“"[T]he only purpose for which power can be rightfully exercised over any member of a civilized community, against his will, is to prevent harm to others. His own good, either physical or moral, is not a sufficient warrant.").

${ }^{245}$ A person who is willing to undergo strict home quarantine to avoid being vaccinated is unlikely to object to the more modest liberty restrictions that a vaccine passport program entails.

${ }^{246}$ See generally MiLL, supra note 244.
} 
above, were arguably sufficiently close. This remarkably high effectiveness led some people to demand that restrictions be lifted for everybody as soon as the vaccines were widely available. In essence, they were arguing that the unvaccinated did not impose any legally relevant negative externalities, because people could essentially protect themselves from those externalities by getting vaccinated.

This argument has some merit, but it also has several limitations. First, some people cannot be successfully vaccinated. For example, the immuno-compromised are often recommended not to receive the measles, mumps, and rubella vaccine. ${ }^{247}$ For COVID-19, a vaccine for those aged 12 to 15 was not available until summer 2021. Although children are at greatly reduced risk of suffering serious effects, children with certain health conditions are at non-trivial risk. ${ }^{248}$ For some adults, like those undergoing chemotherapy, vaccination may not be recommended. ${ }^{249}$ Second, a small fraction of vaccinated adults do develop symptomatic illness. For COVID-19, that group disproportionately comprises the elderly, obese, and immune-compromised. As the CEO of Houston Methodist Hospital, Marc Boom, reasoned in July 2021, "Nine in 10 people in our hospital right now are unvaccinated. So if they had been vaccinated, the other $10 \%$ who are here who are vaccinated probably wouldn't be sick either because we wouldn't have this rate of virus spreading throughout the community." 250

Is it more appropriate, then, to allow those costs to "lie where they fall," that is, for others - those who contract the disease, those denied public-health resources, and the general public - to bear these costs? Or is the government ethically permitted, or even obligated, to transfer these costs back to those who produce them?

The cheapest cost-avoider principle in economics holds that is more efficient - and perhaps normatively preferable - to assign liability to the party better positioned to avoid the costs associated with the externality. ${ }^{251}$ Among other things, this promotes efficiency and total welfare: internalizing externality costs (having to pay for them) will incentivize a person to reduce them. Regardless of whether it is the externality-cost generator or the externality-cost receiver, it is more efficient for the party that can avoid those costs more cheaply to do so.

In the case of vaccines, both the immunized and non-immunized can avoid the externalities resulting from non-immunity, but the non-immunized can surely do so at lower cost. Both the immunized and non-immunized could self-quarantine, avoiding contact with

247 Prevention of Measles, Rubella, Congenital Rubella Syndrome, and Mumps, 2013 Summary Recommendations of the Advisory Committee on Immunization Practices (ACIP), Centers for Disease Control and Prevention (June 14, 2013), https://www.cdc.gov/mmwr/pdf/rr/rr6204.pdf.

248 Lyudmyla Kompaniyets, Nickolas T. Agathis, \& Jennifer M. Nelson, Underlying Medical Conditions Associated with Severe COVID-19 Illness Among Children, 2021 4(6) JAMA Network Open 1, 7-10.

249 COVID-19 Vaccines in People with Cancer, CDC (Aug. 13, 2021), https://www.cancer.org/treatment/treatments-and-side-effects/physical-side-effects/low-blood-

counts/infections/covid-19-vaccines-in-people-with-cancer.html

${ }^{250}$ News Brief: Variant Warning, Biden-Al-Kadhimi Meeting, Climate Meeting, NPR: MoRnING EdITION (July 26, 2021), https://www.npr.org/2021/07/26/1020612067/morning-news-brief (quoting Marc Boom, CEO, Houston Methodist Hospital).

${ }^{251}$ See generally Guido CALABresi, The Costs of ACCIDENTS: A Legal AND EConOMic ANALysis (1970). 
anyone outside their household. As many discovered during the most restrictive periods of the COVID-19 lockdowns, this is an onerous burden. The non-immunized have another option to avoid externalities from non-immunity: getting vaccinated. As discussed, where the vaccine is free and locally and widely available, the costs of doing so pale compared with those of indefinite strict quarantine. This implies that the normatively preferable option is to deny the right to unrestricted public mingling to the non-immunized, i.e., to make the nonimmunized liable for doing so.

Moreover, assigning the liability to the cheapest cost-avoider, the unvaccinated, is likely to nudge some people who would otherwise not get vaccinated to do so, who then generate positive externalities. If the unvaccinated person bears all the costs of not being vaccinated, then, if those costs outweigh the benefits in his mind (which they sometimes or often will), he will get vaccinated.

Indeed, there is both experimental-survey and real-world evidence that freeing the vaccinated from restrictions can be highly effective in promoting vaccinations. In a study conducted by the UCLA Covid-19 Health and Politics Project in March-April 2021, unvaccinated respondents who were told that getting vaccinated would permit them to stop wearing a mask were 13 percentage points more likely to say they would be vaccinated than respondents who were told they would still need to wear a mask after being vaccinated. Give the number of Americans vaccinated then, this 13-point effect translates to about 30 million more vaccinated people. The difference was particularly large among Republicans, whose reported vaccine willingness jumped 18 percentage points. ${ }^{252}$ And in fact, when French President Emmanuel Macron announced he would push for a form of vaccine passport in July 2021, which required a "HealthPass" to patronize cafes, bars, amusement parks, shows, concerts, festivals, and shopping centers, a record number of French citizens, 2.2 million, scheduled vaccinations within the next 48 hours. ${ }^{253}$ Conversely, it appears that instituting harsh restrictions regardless of vaccination status can depress willingness to get vaccinated. Hong Kong, for example, instituted strictly enforced stay-at-home quarantines for all people entering the country, regardless of vaccination status, as well as gathering (no more than four in one place), distancing, and masking requirements for all. According to one observer, "[t]his ham-fisted effort to encourage Hong Kongers to get vaccinated, along with the 'zero COVID' strategy that is still in place, has, if anything, inadvertently undermined any motivation for wavering people to get the jab." ${ }^{254}$ Thus, this evidence suggests that if the rights to comingle in public spaces is not given to non-immunized people, a significant fraction will indeed respond by taking steps to avoid the ensuing costs and get vaccinated.

\footnotetext{
${ }^{252}$ Lynn Vavreck, $\$ 100$ as Incentive to Get a Shot? Experiment Suggests It Can Pay Off, N.Y. TIMES (May 4, 2021), https://www.nytimes.com/2021/05/04/upshot/vaccine-incentive-experiment.html.

253 Roger Cohen, Macron to the French: Vaccinate or Else, N.Y. TIMES (Aug. 5, 2021), https://www.nytimes.com/2021/07/14/world/europe/france-macron-vaccination-coercion.html; see also Bill Chappell, The French Rush For Vaccines After They're Told They'll Need Them To Go To Cafes, NPR (July 13, 2021), https://www.npr.org/sections/coronavirus-live-updates/2021/07/13/1015591406/french-peoplerush-for-vaccines-after-macron-ties-a-new-health-pass-to-cafe-life.

${ }^{254}$ Timothy McLaughlin, The Countries Stuck in Coronavirus Purgatory, ATLANTIC (June 21, 2021), https://www.theatlantic.com/international/archive/2021/06/covid19-zero-asia-hong-kong-quarantine/619231.
} 


\section{A. Individual Liberty}

Some critics of purely economic approaches argue that emphasizing efficiency as a normative goal ignores the notion of rights, marginalizing the politically or economically vulnerable. For example, some libertarian economists and others argue that people should be permitted to volunteer to sell their own organs on a regulated market, as organ markets actually benefit both buyers and sellers and enhance individual rights by respecting potential sellers' rights to control their own bodies. ${ }^{255}$ But some rights-oriented theorists criticize this proposal based on the assumption that donors would disproportionately comprise the poor, for whom the thousands of dollars they might make would be difficult to resist and thus coercive. $^{256}$

Likewise, some may argue that economic justification for discriminating by vaccine status overlooks certain fundamental liberty principles, such as the right to be free from government interference in personal medical decisions. Relatedly, others might respond that constitutional rights by nature cannot be traded away like commodities, and that marketbased analysis is therefore inappropriate here. We therefore consider how liberty principles inform this debate.

Part of the disagreement over vaccine passports appears to stem from differences in how the policy is framed and what the alternative is. ${ }^{257}$ One can conceive of a vaccine restriction exemption program in either of two ways: (1) as creating a set of freeing exemptions (for the vaccinated) within a scheme of universal restrictions, or (2) as a set of restrictions (for the non-immunized) within a scheme that otherwise has few or no restrictions. Before vaccines were available, people with progressive views tended to support general COVID lockdowns and restrictions more than people with conservative and libertarian views. ${ }^{258}$ It is likely that those who oppose restrictions generally imagine that the alternative to vaccine passports is universally no restrictions; thus, why some conservative politicians attack passports as an

\footnotetext{
${ }^{255}$ One of us has made both arguments. See Ilya Somin, Broader Implications of 'My Body, My Choice,' Volokh Conspiracy, REASON (May 10, 2019), https://reason.com/volokh/2019/05/10/broader-implications-ofmy-body-my-choice/; Somin, "Exploitation" of the Poor is a Poor Reason to Ban Organ Markets, VolOKH CONSPIRACY (Jul. 28, 2009), http://volokh.com/archives/archive $200907 \quad 26-$ 200908 01.shtml\#1248767960.

${ }^{256}$ See generally Philip J. Cook \& Kimberly D. Krawiec, If We Allow Football Players and Boxers to Be Paid for Entertaining the Public, Why Don't We Allow Kidney Donors to Be Paid for Saving Lives?, 81 L. \& CONTEMP. PROB. 9 (2018).

${ }^{257}$ Whether people see the concept as novel also seems to affect people's support for vaccine passports. One experimental study of Americans found that telling people that requiring vaccine passports for international travel is not "new" increased respondents' favorability toward the passports. Chiara Sotis, Alessandro Romano, Renny Reyes, \& Miriam Allena, Covid-19 Vaccine Passport and International Traveling: The Combined Effect of Two Nudges on Americans'S Support for the Pass, PSYARXIV (2021), https://psyarxiv.com/dr75j/.

258 Emma Green, The Liberals Who Can't Quit Lockdown, ATLANTIC, https://www.theatlantic.com/politics/archive/2021/05/liberals-covid-19-science-denial-lockdown/618780/ ("In surveys, Democrats express more worry about the pandemic than Republicans do. People who describe themselves as "very liberal" are distinctly anxious.").
} 
assault on "liberty." 259 They view it as a special, targeted deprivation of freedom for the unvaccinated. They may believe that to get rid of vaccine passports is to give everyone freedom, because strict, universal restrictions are an inconceivable alternative.

In contrast, those who support vaccine passports tended to support restrictions generally, ${ }^{260}$ and they probably view passport programs as an appropriate middle-ground between total lockdown and no restrictions at all. Some may assume that the alternative to passports is restrictions for everyone. Notably, many of these supporters likely also believe that the passports further liberty interests, in that they effectively give individuals the power to determine whether or not they are restricted, and because they are likely to hasten the loosening of restrictions for everyone by vanquishing the virus and/or reaching herd immunity faster.

As mentioned, a central principle of liberalism is the presumption that people may do as they like; the government should not coerce people into behaviors only because it believes those behaviors are better for them. ${ }^{261}$ This principle has two main justifications: one deontological, that human liberty has intrinsic value; and the other utilitarian, that people are generally better-positioned than the government to determine what actions best serve their own interests. Indeed, much of the rhetoric opposing vaccine passports and vaccinepromotion policies - including for measles, the seasonal flu, COVID-19, and others characterizes vaccination as a personal choice, akin to how other medical decisions, such as abortion and palliative care, are sometimes framed. ${ }^{262}$ Especially given the intrusive nature of vaccines, some suggest that the government has no right to restrict the liberties of people who have determined that a particular medical procedure is not in their interest.

As discussed above, the consequences of many personal behaviors are not limited to the actor; they affect others positively and/or negatively. Where those effects are sufficiently great or direct, the liberty principle is thought to give way. The utilitarian justification no longer holds (as more total harm would result from permitting the action). The deontological justification remains but is trumped by social welfare concerns. In these cases, it is thought that the law is permitted to intervene to coerce behavior in some manner. The well-known aphorism, "Your right to swing your arms ends just where the other man's nose begins"263 oversimplifies but captures the principle succinctly. As a general rule, the government's

259 E.g., Josh Mandel (@JoshMandelOhio), Twitter (Mar. 30, 2021, 8:14 AM), https://twitter.com/JoshMandelOhio/status/1376870357899051010 (tweeting, "Vaccine passports trample on human liberty.").

${ }^{260}$ Cf. Carlie Porterfield, U.S. Voters Are Narrowly In Favor Of Vaccine Passports, Poll Suggests, ForbeS (Apr. 7, 2021), https://www.forbes.com/sites/carlieporterfield/2021/04/07/us-voters-are-narrowly-in-favor-ofvaccine-passports-poll-suggests/ (showing that Democrats show greater support for vaccine passports).

${ }^{261}$ See MiLl, supra note 244.

262 Joel Mathis, Vaccination is Not a Personal Choice, Week, Aug. 11, 2021, https://theweek.com/science/health/1003617/vaccination-is-not-a-personal-choice.

${ }^{263}$ The aphorism has uncertain origins, but it is thought to have originated sometime in the late nineteenth century. It was expressed in a 1919 article by Zechariah Chafee in the Harvard Law Review. Zechariah Chafee, Jr., Freedom of Speech in War Time, 32 HARV. L. REV., 932, 957 (1919) (related by an anonymous judge). 
intervention is justified only if it is the least intrusive or coercive measure required to induce the desired - i.e., non-harmful - behavior. ${ }^{264}$

The question, then, is does non-vaccination affect others sufficiently to overcome the liberty principle? The answer surely depends on many factors, including the transmissibility of the disease and the expected consequences of contracting it. In some situations, it may be that vaccination requirements are unjustified, either because they pose too great a threat to liberty, the vaccines do not effectively constrain the spread of the disease, or some combination of both. But, particularly in the former scenario, more extreme restrictions on liberty, such as lockdowns and travel restrictions that do not distinguish the vaccinated from the unvaccinated - would be even less defensible.

Compared to nearly all other public-health restrictions, a vaccination requirement is a relatively modest infringement on liberty. Once the person gets his or her "jab," they are able to go on with their lives, as before. By contrast, lockdowns, mask mandates, and travel restrictions create severe ongoing constraints on liberty. This distinction may not matter in situations where even the slightest constraints on liberty are unjust. But it is crucial in cases where at least some restrictions are defensible, and policymakers face a choice between more severe constraints and less severe ones. Vaccination will almost always fall in the latter category, and is thus almost always preferable from a perspective that places a high value on individual freedom.

As mentioned, the COVID-19 vaccines' effectiveness varies over time, by type of vaccine, and which COVID-19 variant is dominant, but it can reach $90 \%$ or higher. COVID19 's infection-fatality rate across all age groups is thought to average about $0.4 \%$. Specific estimates are difficult to calculate due to many confounding factors, but it seems likely that a non-immunized person is at least several times as likely as a nonimmunized person to be currently infected and contagious with COVID-19.

Does the liberty principle require people to accept these levels of external dangers produced by others' decisions as the price of liberty? Or are these effects sufficient to constitute the metaphorical hand-hitting-nose? There is no formula for answering this question. Regardless, to do so, it is helpful to compare the behavior of non-vaccination to others about which we have well-established normative beliefs.

For instance, most (not all, as discussed above) people in the United States seem to accept the validity of requiring public-school children to be vaccinated against polio; that vaccine is up to $99 \%$ effective for a disease that killed up to $5 \%$ of infected children and caused crippling disability in many more. ${ }^{265}$ As another example, a consensus exists that it is not inconsistent with a free society for the government to prohibit people from driving a car while drunk. For other, less serious behaviors and diseases, the moral calculus changes. For instance, around 40,000 Americans die of the seasonal flu each year on average. Although vaccination is required for health-care workers in some states, there has been no serious discussion in the United States of implementing a flu-vaccine mandate for the general

\footnotetext{
${ }^{264}$ NAACP v. Alabama, 357 U.S. 449 (1958) ("The breadth of legislative abridgment must be viewed in the light of less drastic means for achieving the same basic purpose.").

${ }^{265}$ See Pinkbook: Poliomyelitis, CDC (Nov. 2020), https://www.cdc.gov/vaccines/pubs/pinkbook/polio.html.
} 
population. ${ }^{266}$ The reason is likely twofold: the vaccine is only moderately effective ( $41 \%$ effectiveness on average $\left.{ }^{267}\right)$, and the seasonal flu has a low overall fatality rate $(0.02 \%$ $0.1 \%) .{ }^{268}$ It seems likely that most people would consider risk and benefits associated with COVID-19 vaccines more similar to those associated with drunk driving and polio vaccines, rather than those associated with the seasonal flu.

This does not necessarily mean that excluding the vaccinated from all or most public spaces is justified. Comprehensive exclusion might impose severe costs that outweigh any likely benefits. The point of this article is not that any and all restrictions on the vaccinated are justified, but that such restrictions are sometimes defensible, especially if the only realistically feasible alternative is to impose restrictions on everyone, regardless of vaccination status.

\section{B. Discrimination and Social Stratification}

Is treating the vaccinated differently from the unvaccinated consistent with the principle of non-discrimination? Many legal systems around the world contain some version of the principle that, in general, people should be treated equally. That is, the government and private actors should treat "similarly situated" people similarly. To do otherwise is deemed unjust discrimination, and is usually disincentivized by, among other things, making it grounds for a civil cause of action. Under U.S. law, that principle is codified, among other places, in the Equal Protection Clause of the Fourteenth Amendment. ${ }^{269}$

As with many legal and moral principles, the nondiscrimination principle as currently understood is not grounded in a single coherent theory of just discrimination. It has evolved over a century-and-a-half based on a variety of competing theories and ad hoc, fact-driven justifications. But despite a lack of consensus theory underlying the principle, most scholars and the Supreme Court view the principle as primarily intended to act "as a shield against arbitrary classifications." ${ }^{270}$ The Court has stated that " $[\mathrm{t}]$ he purpose of the equal protection clause of the Fourteenth Amendment is to secure every person . . . against intentional and arbitrary discrimination, whether occasioned by express terms of a statute or by its improper execution through duly constituted agents." 271 Assuming this view is correct, it leaves open

\footnotetext{
${ }^{266} C f$. Michael B. Edmond, Mandatory Flu Vaccine for Healthcare Workers: Not Worthwhile, 6 OpEN FoRUM INFECT Dis. (2019).

${ }^{267} I d$.

${ }^{268}$ National Center for Health Statistics, Influenza, https://www.cdc.gov/nchs/fastats/flu.htm.

${ }^{269}$ U.S. CONST. amend. XIV, $\S 1$.

${ }^{270}$ Engquist v. Or. Dep't of Agric., 553 U.S. 591, 598 (2008); see Earl A. Maltz, The Concept of Equal Protection of the Laws-A Historical Inquiry, 22 SAN DIEGO L. REV. 499 (1985) (observing that all mainstream theories of the drafters' intent see the Equal Protection Clause as "having been aimed at the elimination of particularly obnoxious classifications); but see Christopher R. Green, The Original Sense of the (Equal) Protection Clause: Pre-Enacting History, 19 Geo. MASON U. C.R. L.J. 1 (2008) (arguing that the clause does not primarily prohibit arbitrary classifications, but rather creates a general "duty. . . to protect all persons and property within its jurisdiction from violence and to enforce their rights through the court system").

${ }^{271}$ Vill. of Willowbrook v. Olech, 528 U.S. 562, 564 (2000) (quoting Sioux City Bridge Co. v. Dakota County, 260 U.S. 441, $445(1923))$.
} 
the question: what does it mean for a classification to be "arbitrary," and thus impermissible?

Surveying the body of caselaw and literature on when government discrimination is permissible, a set of three salient criteria emerge. The government's intentionally denying rights or benefits to some but not others is more likely to be deemed just where: (1) the underlying trait (the basis for the adverse classification) is voluntarily acquired; (2) that trait imposes substantial harm on others, which the discriminatory policy could mitigate; and (3) the discriminatory policy is short in duration. ${ }^{272}$ In addition, it may also be significant that the criterion at issue not have a history of being used a tool of oppression. These elements are not conjunctive or disjunctive but considered collectively, along a sliding scale. Thus, in some limited cases where the underlying trait was not voluntarily acquired, it may still be permissible to discriminate where the trait causes sufficient harm. This is especially true where the government is providing an affirmative benefit versus imposing a harm. And in some cases where the trait causes little harm, it might be acceptable to discriminate where the trait is voluntarily acquired and the restriction is short in duration.

Even people who agree with these criteria in principle will often disagree about the level of harm that should be sufficient to meet the second element. Nonetheless, if the four elements are present, discrimination is more likely to be justifiable. Consider that, in the United States, state and federal law commonly deprives people convicted of felonies from possessing firearms, an otherwise arguably fundamental right in the United States. ${ }^{273}$ The rule is arguably justified because committing a felony is usually a voluntary decision, and because allowing violent felons to possess firearms might result in more violence to others. But others argue that the externalities are not significant enough to justify the broad, sometimes decade-plus or lifetime-long rule, in part because it can apply to every type of crime (e.g., tax evasion), not just those involving guns or violence. ${ }^{274}$ Also for that reason, some might argue that the restriction is not the least intrusive means of achieving the end.

By these four criteria, vaccination requirements stack up well. Not being vaccinated in places where vaccines are free and widely available is a voluntary decision, except perhaps for those who are not medically disqualified from receiving them. ${ }^{275}$ The extent of the harms inflicted on others is covered above in the discussion of externalities above. In any given

\footnotetext{
${ }^{272}$ This exception follows from the two justifications for the liberty principle. While liberty has value, other values exist which may be in tension, and so it may sometimes give way to competing values, like freedom from physical harm. As to the second premise, while an actor is better positioned than the government to determine what serves his own interests, that actor is generally worse positioned than the government to determine what serves the interests of a third party. Indeed, the actor may have little knowledge of third-party interests and may experience none of the benefits or harms experienced by the third-party because of the action. In contrast, the government is formally tasked with care for the third-party's interests, and in democratic systems, he can communicate those interests and attempt to have them reflected in policy.

${ }^{273}$ McDonald v. Chicago, 561 U.S. 742 (2010) (holding that "individual self-defense is 'the central component' of the Second Amendment right" and that "[s]elf-defense is a basic right" (quoting District of Columbia v. Heller, 554 U.S. 570, 599 (2008)).

274 See Michael Luo, Felons Finding It Easy to Regain Gun Rights, N.Y. Times (Nov. 13, 2011), https://www.nytimes.com/2011/11/14/us/felons-finding-it-easy-to-regain-gun-rights.html.

${ }^{275}$ For those who object on religious grounds, the question of voluntariness is more controversial.
} 
instance, the harm is uncertain; in the aggregate, the harm is better-documented and can be substantial. As with the measles outbreaks of the 2010s, growing numbers of unvaccinated resulted in numerous outbreaks - including some among the vaccinated - where the unvaccinated had gathered in close proximity, including at Disneyland in 2015. ${ }^{276}$ In the case of COVID-19, the strong effectiveness and relative ease of transmission implies a substantial harm of non-vaccination. Finally, if it is effective at promoting vaccination and stymying the development of variants, the distinction between immunized and non-immunized is likely to be lifted after a fairly short time. Indeed, Israel repealed its vaccine Green Pass system after just four months, after new infection rates fell to negligible levels. ${ }^{277}$ Though, sadly, it has recently been revised with the emergence of the more transmissible Delta variant.

Discrimination against the unvaccinated can often be limited to a relatively short duration, assuming that enough people become vaccinated to get the disease outbreak under control. In addition, most unvaccinated people can quickly escape the discrimination in question by the relatively simple means of getting the vaccination. This contrasts with the plight of most victims of discrimination on the basis of race, ethnicity, gender, and sexual orientation, for whom it is difficult or impossible to escape the status that triggers discriminatory treatment.

Finally, unlike discrimination on the basis of criteria such as race, gender, religion, and sexual orientation, there is no extensive history of oppression arising from discrimination against the unvaccinated. No society of which we know has created a permanent underclass of unvaccinated people who are treated as second-class citizens or worse, in the way, Blacks were treated under South African apartheid and Jim Crow, or women are treated in patriarchal societies. Part of the reason why such stratification has not emerged may be that the unvaccinated can easily escape their distinctive status. In addition, the emergencies that lead to discrimination against the vaccinated subside over time (often faster precisely because of vaccination). By contrast, we often cannot count on racial, ethnic, religious, and other bigotry to subside in the same way. These considerations do not prove that long-term invidious discrimination against the unvaccinated could never arise. But they do suggest the risk is much lower than with various types of discrimination that are now banned or severely restricted under American constitutional principles.

These four factors each suggest that it is often ethically permissible for the government to discriminate against the non-immunized, especially where vaccines are widely available at little or no cost. We should not assume that discrimination against the unvaccinated is always ethically permissible. But it will sometimes be so in situations where there is an ongoing danger of spreading deadly, contagious diseases.

\footnotetext{
276 Jenny Marder, You Could Get the Measles, Even if You're Vaccinated, PBS (Jan. 28, 2015), https://www.pbs.org/newshour/nation/whos-risk-measles-maybe-think.

${ }^{277}$ Isabel Kershner, With Most Adults Vaccinated and Case Numbers Low, Israel Removes Many Restrictions., N.Y. TIMES (Jun. 1, 2021), https://www.nytimes.com/2021/06/01/world/middleeast/israel-covidrestrictions.html.
} 


\section{Disparate Impact by Ethnic Group}

Some have argued that, since some demographic groups like Blacks, Latinos, and Indigenous people have lower rates of COVID-19 vaccination, ${ }^{278}$ denying rights and privileges to the unvaccinated would adversely impact those groups. ${ }^{279}$ No doubt, historical and present inequity in vaccine distribution is concerning and needs to be better addressed. But the likely effect of vaccine passports is to better protect everyone from the disease, especially members of ethnic minority groups and the socio-economically disadvantaged.

Discrimination theory distinguishes between disparate treatment and disparate impact. Disparate treatment involves a policy or decision's intentionally treating groups differently, whereas disparate treatment involves a formally neutral policy or decision that nonetheless affects groups differently in practice. Both can be morally justified or unjustified (as well as lawful or unlawful) depending on many factors. But all things being equal, disparate treatment is usually considered more pernicious and difficult to justify. We are not aware of any evidence that vaccine disbursement programs in the United States deliberately or formally discriminate on the basis of race or ethnicity. Rather, some have noted that the vaccination rates are nonetheless different for different ethnic groups. ${ }^{280}$ The reason for this difference is not well understood, but some speculate that some reasons include: AfricanAmericans' longtime skepticism toward healthcare institutions generally; ${ }^{281}$ fewer vaccine distribution centers in predominantly Black neighborhoods; ${ }^{282}$ Asians' and Whites' greater average work-schedule flexibility versus that for Blacks and Latinos; and that people lacking lawful immigration status, who are disproportionately Latino, may be deterred by the fact that the military runs many vaccination sites. ${ }^{283}$ The question of whether public-health authorities should ensure that all groups have equal opportunities for vaccination - which we believe they should - is different from the question of whether the existing disparities in coverage are sufficient grounds for rejecting vaccine passport programs altogether - which we believe they are not.

278 Latest Data on COVID-19 Vaccinations by Race/Ethnicity, KFF (July 21 ,2021), https://www.kff.org/coronavirus-covid-19/issue-brief/latest-data-on-covid-19-vaccinations-race-ethnicity/ (Figure 3 and 4).

279 Ryan Tanner \& Colleen M. Flood, Vaccine Passports Done Equitably, Jama Health Forum (Apr. 21, 2021), https://jamanetwork.com/channels/health-forum/fullarticle/2779298.

${ }^{280}$ Marissa Reitsma et al., Disparities in Reaching COVID-19 Vaccination Benchmarks: Projected Vaccination Rates by Race/Ethnicity as of July 4, KFF (Jun. 14, 2021), https://www.kff.org/racial-equity-and-healthpolicy/issue-brief/disparities-in-reaching-covid-19-vaccination-benchmarks-projected-vaccination-rates-by-

race-ethnicity-as-of-july-4/ ("Asian people are the only group estimated to exceed a 70\% vaccination rate, while White people $(66 \%)$ and Hispanic people $(63 \%)$ will be shy of reaching this level, and only about half (51\%) of Black people will have received at least one COVID-19 vaccine dose by July 4, based on current trends").

${ }^{281}$ Jack Dutton, Why Black Americans Are Less Likely to Take the COVID Vaccine, NewsweEK (Feb. 19, 2021), https://www.newsweek.com/why-black-americans-are-less-likely-covid-vaccine-1570521

${ }^{282}$ Alex Samuels, The Reason Black Americans Are Getting Vaccinated At a Much Slower Rate Is Not Because They're Reluctant, FIVETHIRTYEIGHT (Mar. 9, 2021), https://fivethirtyeight.com/features/why-fewer-blackamericans-are-getting-the-covid-19-vaccine-no-its-not-hesitancy/.

${ }^{283} \mathrm{Id}$. 
In thinking about how vaccine passports would exacerbate inequalities, we must consider their full policy impact- including on health and economic welfare. Well before the introduction of vaccines, the COVID-19 pandemic in the United States disproportionately affected Blacks and Latinos. Those groups were more likely than Whites and Asians to contract COVID-19 and more likely to be hospitalized and die from it. The reasons for these disparities are not fully understood, but some have speculated that factors include: the fact that Blacks and Latinos are more likely to live in urban areas where distancing is more difficult; Blacks' and Latinos' worse access to quality health care; the higher incidence of certain vulnerability-producing health conditions in Blacks such as heart disease and diabetes; and the fact that Blacks' and Latinos' disproportionately hold jobs that made them vulnerable to COVID-19. ${ }^{284}$ Such jobs included those that carried greater risk of exposure to COVID-19 or were impossible to perform remotely. ${ }^{285}$

Early in the COVID-19 pandemic, most jurisdictions made policy decisions to partially shut down the economy. Some businesses were closed altogether, but several sectors like financial and legal services, education, and other white-collar occupations stayed largely open but moved virtual, protecting those workers from exposure, without significantly reducing their incomes or forcing them into unemployment. By contrast, businesses such as restaurants and other in-person service providers were disproportionately targeted by shutdowns. Some minority groups, such as Blacks and Latinos, are disproportionately represented in these industries, and therefore were more likely to suffer reductions in pay or go into unemployment. ${ }^{286}$ Vaccine passports are likely to have less disparate impact on minorities than lockdowns and other more severe restrictions on social and commercial activity. For those considered about disparate racial impact, this reality should at least be considered in developing a pandemic policy response.

A body of evidence, partially summarized above, suggests that a functional system of vaccine passports would protect more people from disease and expedite the return to full social and economic normalcy. Dismissing vaccine passports out of concern for exacerbating group inequities would unintentionally reinforce the health inequities that these groups have already suffered, partly as a result of government policy. Given the fact that vaccines are generally available to all adults, nearly everyone has the choice to get vaccinated. Workers exposed to people infected with COVID-19 as part of their job have much less meaningful choice about incurring that risk. The same goes for those forced to accept pay cuts or unemployment as a result of lockdowns. Considering these realities, the more moral policy

\footnotetext{
${ }^{284}$ See Shanoor Seervai, Why Are More Black Americans Dying of COVID-19?, Dose (June 26, 2020), https://www.commonwealthfund.org/publications/podcast/2020/jun/why-are-more-black-americans-dyingcovid-19.

${ }^{285}$ See Paul Biasco, As Americans Go Back to Work, These Are the 9 Riskiest Jobs to Have In the Middle of the Pandemic, BusINESS INSIDER (July 13, 2020), https://www.businessinsider.com/riskiest-jobs-aftercoronavirus-lockdowns-lift-2020-6\#4-flight-attendants-6.

${ }^{286}$ See, e.g., Congressional Research Service, Unemployment Rates During the Covid-19 Pandemic, July 15, 2021, available at https://fas.org/sgp/crs/misc/R46554.pdf (finding higher shutdown and pandemic-related unemployment among black and Hispanic workers); Jaison R. Abel and Richard Deitz, Some Workers Have Been Hit Much Harder than Others by the Pandemic, Fed. Res. Bank of New York, Feb. 9, 2021, available at https://libertystreeteconomics.newyorkfed.org/2021/02/some-workers-have-been-hit-much-harder-thanothers-by-the-pandemic/.
} 
option is the one that empowers everyone to simultaneously avoid unemployment, restore their liberties, and better protect their health.

\section{Practical Challenges to Judicially Mandated Vaccine Passports}

We have covered the substantive doctrinal arguments and ethical considerations relevant to a judicially created vaccine passport. How then, logistically, would it emerge, especially given the challenges of an evolving pandemic?

\section{A. Logistics}

An immunized person who is subject to certain pandemic-related restrictions might file suit against a (likely state or local) government that is imposing these restrictions, making this set of arguments. At least where strict or intermediate scrutiny applies, the burden of proof would fall on the government to show that its policy restricting the immunized is appropriately tailored given the immunization-effectiveness levels and transmission risks as currently understood. ${ }^{287}$ For relief, she would seek an order enjoining the governmentdefendant from applying the pertinent restriction(s) to her. If she were successful, in most cases it might be easier to exempt the entire set of potential future plaintiffs (i.e., the immunized) than to create special rules for an individual or small set of people. A judicially created exemption regime that would mimic the effects of a legislatively created vaccinepassport system could emerge from this process.

Even before the introduction of vaccines during the COVID-19 pandemic, courts in the United States and elsewhere showed some willingness to strike down or constrain restrictions as unconstitutionally overbroad or irrational, even though courts typically give more deference to official judgments in times of threats to national security or public health. Without taking a position on whether any of these cases were rightly decided, we note only that they offer insight into the viability of a lawsuit demanding exemptions from publichealth restrictions. Many anti-restriction lawsuits filed before the introduction of vaccines had little merit, and most failed. ${ }^{288}$ Nonetheless, courts were willing to invalidate certain measures where they determined that the challenged regulation was not narrowly or otherwise appropriately tailored. For instance, a U.S. district court struck down Pennsylvania Governor Tom Wolf's executive orders that limited indoors gatherings to 25 people, required staying at home, and mandated closures of "non-life-sustaining" businesses, as violations of the First and Fourteenth Amendments. ${ }^{289}$ The injunction went into effect

\footnotetext{
287 See, e.g., Page v. Cuomo, 478 F. Supp. 3d 355, 365 (N.D.N.Y. 2020) (holding that COVID-19 restrictions burdening fundamental rights must be "narrowly tailored" and serve a "compelling Government interest") (internal citations omitted).

${ }^{288}$ See, e.g., Sophie Quinton, GOP Lawsuits Restrain Governors' COVID-19 Actions, PEW (Nov. 17, 2020), https://pew.org/3nzlwL1 ("Judges have tossed out the lawsuits or sided with governors in most states where cases have been filed.").

${ }^{289}$ Butler v. Wolf, 486 F. Supp. 3d 883 (W.D. Pa. 2020).
} 
statewide, but was later stayed by the Third Circuit. ${ }^{290}$ The U.S. District Court for the Eastern District of Kentucky invalidated Kentucky's ban limiting interstate travel. ${ }^{291}$ In Brach v. Newsom, the Ninth Circuit reversed summary judgment for the defendant state of California and held that the state's forced closure of private schools implicated a fundamental interest and that the state's policy was not narrowly tailored to achieve the state's interest. ${ }^{292}$ Other decisions affected stay-at-home orders and school reopenings. ${ }^{293}$ Outside the United States, in March 2021, the Israeli Supreme Court invalidated a national law limiting the number of citizens who could enter the country to 3,000 per day. ${ }^{294}$ In February 2021, a Dutch court ordered the government to lift a nationwide curfew, calling it a "far-reaching violation of the right to freedom of movement and privacy" and holding that the measure was wrongly enacted pursuant to the government's emergency powers. ${ }^{295}$

In each of the cases, the court enjoined the government from enforcing the challenged policy against everyone. The logistics of implementing such orders against state and local officials are well-established and relatively straightforward. ${ }^{296}$ In contrast, a claim by an immunized person would seek exemption from particular restrictions for herself. And given that states and municipalities implement most pandemic restrictions, the defendant would likely a state or local official, not a federal one. The judgement might extend, however, to other immunized people within the jurisdiction. First, it is possible that many plaintiffs would join the suit, either via a traditional civil action or a class action. Even if not, a court might simply enjoin the government from imposing the relevant restriction on all those similarly situated to the plaintiff, i.e., immunized people. Regardless, if appellate affirmation created precedent, that ruling would effectively prevent that and other governments from enforcing both the challenged restriction and similar restrictions against similarly situated persons, i.e., a vaccinated or otherwise immune person. In theory, this would effectively force governments to attempt to develop a system for selectively enforcing the restrictions. And even if a trial court's order formally applied only to one or a few named plaintiffs, a government may wish to avoid the ordeal of further litigation and opt to change its policy universally.

How feasible would this be? This question implicates more than just a post-judgement bureaucratic challenge; the feasibility of providing the exemption may affect whether the plaintiff would prevail in the first place. As discussed, regardless of the level of scrutiny,

\footnotetext{
${ }^{290}$ Butler v. Governor of Pennsylvania, No. 20-2936, 2020 WL 5868393, at *1 (3d Cir. Oct. 1, 2020).

${ }^{291}$ Roberts v. Neace, 457 F. Supp. 3d 595 (E.D. Ky. 2020).

${ }^{292}$ Brach v. Newsom, No. 20-56291, 2021 WL 3124310 (9th Cir. July 23, 2021)

${ }^{293}$ See also Bailey v. Pritzker, 3:20-cv-00474 (S.D. Ill. 2020) (invalidating governor's stay-at-home order only as to plaintiff); A.A. v. Newsom, 37-2021-00007536 (Sup. Ct. Cal. Mar. 15, 2021) (schools reopening). Courts in the United States also struck a number of state ordinances on procedural or separation-of-powers grounds, including mask mandates in Wisconsin. E.g., Fabick v. Evers, No. 2020AP1718-OA (Wis. Mar. 31, 2021) (striking governor's mask mandate as outside his executive authority).

${ }^{294}$ Netael Bandel, Top Court Strikes Down COVID Restrictions on Citizens' Entry and Departure from Israel, HAARETZ (Mar. 17, 2021), https://www.haaretz.com/israel-news/.premium-top-court-strikes-down-covidrestrictions-on-entry-and-departure-from-israel-1.9627512.

295 Dutch Court Orders Government to Lift Covid Curfew, France 24 (Feb. 16, 2021), https://www.france24.com/en/live-news/20210216-dutch-court-orders-government-to-lift-covid-curfew.

${ }^{296}$ See Ex Parte Young, 209 U.S. 123 (1908).
} 
one element of a substantive due process case is whether the challenged restriction is welltailored to meet the government's objective. In performing this analysis, courts inevitably compare the government's existing policy with feasible potential alternatives. If there are none - because selectively applying rights and benefits would be logistically difficult or impossible - courts would be more likely to determine that the challenged universal restriction passes muster. Conversely, if the identified, less-liberty-infringing alternative has already been implemented with reasonable ease, cost, and success elsewhere, it might make the challenged restriction seem less "narrow" and "rational" in comparison, making a court more likely to invalidate it.

As covered above in the Part II discussion of vaccine credentials, technology firms have already developed the technology for a digital health pass, for the purpose of partnering with governments for just such a purpose. As mentioned, New York State has already implemented its IBM-developed Excelsior Pass, and many places of businesses, as well as municipalities like New York City, used the pass to implement selective restrictions. ${ }^{297}$ In principle, implement vaccination passports should be no more difficult than implementation of many longstanding rules requiring presentation of licenses or IDs to participate in various activities or receive government services. Examples include ID requirements for flying on a plane, drivers' licenses, and others.

We suspect that many state and local leaders of jurisdictions that are politically leftleaning or moderate would prefer - for many of the reasons discussed in Part V above - to selectively tailor restrictions to the non-immunized. But they may think the issue is too polarizing to do so. If this is true, some governments might conceivably welcome a legal challenge of the type this Article describes.

\section{B. Relevance Through an Evolving Pandemic}

We have noted that one of the assumptions underlying our argument is the availability of safe, effective vaccines. But of course, public-health experts' understanding of how a pandemic and its vaccines work changes constantly, creating significant uncertainty among policymakers and the public. For instance, studies on vaccine effectiveness against the COVID-19 Delta variant are mixed. One study from Israel found that the Pfizer-BioNTech vaccine was only $64 \%$ effective at preventing symptomatic disease, whereas a later U.K.based study published in the New England Journal of Medicine found "[o]nly modest differences in vaccine effectiveness" against the Alpha variant relative to the Delta variant, for instance, $93.7 \%$ versus $88 \%$ effectiveness for two doses of the Pfizer-BioNTech vaccine. ${ }^{298}$ How easily an infected person can transmit the Delta variant to others is also uncertain. One U.K.-based study (currently undergoing peer review) of the Delta variant

\footnotetext{
${ }^{297}$ Syd Stone, Here's How to Get the Excelsior Pass Now that NYC Will Soon Require Proof of Vaccination, MARKETWATCH (Aug. 4, 2021), https://www.marketwatch.com/story/heres-how-to-get-the-excelsior-passnow-that-nyc-will-soon-require-proof-of-vaccination-11628104401 (explaining the use of Excelsior Pass for indoor activities).

${ }^{298}$ Jamie Lopez Bernal, et al., Effectiveness of Covid-19 Vaccines against the B.1.617.2 (Delta) Variant, New ENG. J. MED. (Aug. 12, 2021), https://www.nejm.org/doi/full/10.1056/NEJMoa2108891.
} 
found significantly lower viral loads in vaccinated infected people relative to unvaccinated infected people. ${ }^{299}$ According to the study, these values among vaccinated people "indicate lower infectiousness, consistent with transmission studies conducted when the Alpha variant was dominant, in which vaccinated individuals were at substantially lower risk of passing on infection." Another study from Singapore found comparable viral loads during the first week of Delta-variant infection, but much lower loads for vaccinated people thereafter. ${ }^{300}$

Nonetheless, the emergence of more infectious strains of COVID-19 complicates the argument for mandatory restriction exemptions. First, transmissibility of the disease among the unvaccinated increased, making the overburdening of the health-care system once again a real threat to everyone. Second, the increase in daily new cases significantly increases the risk of infections for those who cannot get vaccinated. Third, the Delta strain might be more dangerous for children than previous variants. Fourth, the probability of breakthrough infections in those vaccinated increased significantly, although the risk of severe illness is still exceedingly small. Fifth, it highlights the danger that even more dangerous mutations might arise in the future.

These developments complicate the picture but do not meaningfully undermine the argument. This is true for several reasons. First, as mentioned, new vaccines are rapidly being developed, both to target new strains and for younger children. Second, the unvaccinated are the main drivers of viral spread, as they are at three-to-eight times more likely to get infected. The large numbers of unvaccinated make space for new even moreinfectious variants to emerge. Moreover, controlling for age, the unvaccinated are 30 times as likely to develop severe disease and be hospitalized. ${ }^{301}$ They are therefore the main drivers behind overburdened hospitals and the use of medical resources to fight COVID. While it is possible for vaccinated people to transmit the virus, their risk to other successfully vaccinated people is extremely low, probably at risk levels below the seasonal flu.

Regardless, during a pandemic, the relevant immunity, transmission, and other statistics can be a moving target. But one of the advantages of electronic vaccine passports is their potential flexibility. They can be tailored and updated as more information emerges about the immunity levels conferred by different types and doses of vaccine. As new variants or new information about immunity levels emerges, it might be appropriate to suspend or modify the passport's benefits based on vaccine history until more effective vaccines are available. A court considering a claim seeking restriction exemption would consider the scientific information currently available. But, ideally, state or local public-health agencies would assume this responsibility in cooperation with elected officials, at the behest of the court, or on their own initiative.

${ }^{299}$ Paul Elliott et al., REACT-1 Round 13 Final Report: Exponential Growth, High Prevalence of SARS-Cov-2 and Vaccine Effectiveness Associated With Delta Variant in England During May To July 2021 (Aug. 4, 2021), http://hdl.handle.net/10044/1/90800 (unpublished manuscript).

${ }^{300}$ P. Y. Chia et al., Virological and Serological Kinetics of SARS-Cov-2 Delta Variant Vaccine-Breakthrough Infections: A Multi-Center Cohort Study (2021), https://doi.org/10.1101/2021.07.28.21261295 (unpublished manuscript).

301 See Fight COVID MKE COVID-19 Individual Risk Estimator, at https://fightcovidmilwaukee.org/individual-risk-estimator (last visited Aug. 15, 2021). 


\section{CONCLUSION}

Large-scale crises like pandemics are commonly thought to pit civil liberties against the economy and human life. Pandemics sometimes do call for difficult tradeoffs on this dimension. But policymakers must still work within constitutional constraints. Based on our analysis above, we conclude that governments in the United States might not only be morally required, but also constitutionally obligated, to exempt immunized people from certain onerous public-health restrictions.

To reiterate the scope of our argument, we do not suggest that the government is constitutionally powerless to impose any burdens on vaccinated people. First, it is sometimes impossible or impractical to distinguish between the vaccinated and non-immune; in these cases, imposing a public-health-related restriction universally might be the most rational policy. Conversely, by arguing that immunized people are constitutionally entitled to a vaccine passport for some types of restrictions, we do not suggest that the immunized have a constitutional right to have restrictions imposed on the non-immune. ${ }^{302}$ During the COVID19 pandemic, many jurisdictions in the world opted to lift most restrictions on everyone, despite emerging more-infectious variants and growing case numbers. To analogize to international travel passports, those documents (along with visas) allow their holders to pass through a country's borders, whereas people without them are restricted from doing so. But if all border restrictions were lifted and a system of open borders were instituted, those passports and visas would be obsolete - effectively, everyone would hold the equivalent of a passport and entry visa! Thus, under this framework, those jurisdictions that have lifted all pandemic restrictions have essentially given everyone a vaccine passport. While doing so may be bad public-health policy, it obviates the constitutional need for a judicially created vaccine passport.

This Article's analysis and conclusions are therefore not particular to one strand, disease, or crisis. Assuming our core conditions are satisfied, they apply retroactively to diseases of the past, such as polio, measles, and smallpox, and to potential future outbreaks, which some epidemiologists predict could become more frequent in the future as a result of globalization, antibiotic-resistant infections, climate change, and even bioterrorism. ${ }^{303}$

According to political University of Sydney political scientists Tim Soutphommasane and Marc Stears, "COVID-19 will be with the world for at least the foreseeable future," becoming endemic, meaning that the challenge for health policy will be "to learn to live with the virus effectively, protecting public health while restoring freedoms." 304 Exempting the

\footnotetext{
${ }^{302}$ State laws and orders banning private organizations from requiring vaccination could be unlawful, on the theory that they interfere with business operations, property rights, free expression, the dormant Commerce Clause, or statutory provisions. See, e.g., Liz Stark, Norwegian Cruise Line Can Require Proof of Covid-19 Vaccination in Florida, Federal Judge Rules, CNN (Aug. 9, 2021), https://www.cnn.com/travel/article/floridacruise-covid-19-vaccination-proof/index.html. But they are beyond the scope of this Article.

${ }^{303}$ See Mandal, supra note 17; Murdoch, supra note 17; Novella, supra note 17.

${ }^{304}$ Tim Soutphommasane \& Marc Stears, Zero-COVID Is No Longer an Effective Strategy. We Need to Learn From Other Countries How to Adapt, CONVERSATION (July 28, 2021), https://theconversation.com/zero-covidis-no-longer-an-effective-strategy-we-need-to-learn-from-other-countries-how-to-adapt-165241.
} 
fully immunized from certain onerous restrictions is a constitutional - and constitutionally mandated - tool which promotes both goals. 